\title{
PARTITION OR PERISH: RESTORING SOCIAL EQUILIBRIUM IN NIGERIA THROUGH RECONFIGURATION
}

\section{Okechukwu Oko*}

\section{INTRODUCTION}

Ethnic identity is central to the life of Africans. ${ }^{1}$ An individual's ethnic identity helps to shape perceptions, political behavior, ${ }^{2}$ and even personal relationships. ${ }^{3}$ Prospects of a better life, such as access to modern facilities, adequate health care, and state appointments, far too often depend on an African's ethnicity. ${ }^{4}$ Fear of exclusion from power, and by extension from the nation's wealth, is genuine and remains a major impetus for aggressive ethnic identification in most African countries. ${ }^{5}$ The fear of losing control of the machinery of government to another ethnic group reinforces the

* LL.B. (Hons), LL.M. (University of Nigeria); LL.M., J.S.D. (Yale Law School); Assistant Professor, Southern University Law Center, Baton Rouge, Louisiana. I gratefully acknowledge the useful comments and suggestions by Professor $Q$. Johnstone, Professor Emeritus, Yale Law School. I also wish to thank Triscilla Taylor, J.D. '98, and Lakoshia Roberts, J.D. '99, for their invaluable research assistance.

1. A. Selassie, Ethnic Identity and Constitutional Design for Africa, 29 STAN. J. INT'L L. 1, 12 (1992) ("Ethnicity tends to be more important to Africans than it is to individuals elsewhere. In much of Africa, ethnicity is the hub around which life revolves."); GERHARD MARE, ETHNICITY AND POLITICS IN SOUTH AFRICA 2 (1993) ("Ethnic identity is similar to a story; it is a way of dealing with the present through a sense of identity rooted in the past.").

2. Rotimi Suberu, Comment, Federalism and Nigeria's Political Future, 87 AFR. AFFAIRS 431, 437 (1988) (commenting that in spite of remarkable institutional and constirutional reforms designed to reduce their impact on political life, ethnicity and religion still provide the basis on which political values are defined, articulated, contested or challenged) (citing Shehu Othman, The Triumph of Theater, W. AFR., June 15, 1987, at 1142).

3. Sara-Wiwa's Peril, ECONOMIST, Nov. 4, 1995, at 46 (noting that in Nigeria, as in all of Africa, ethnicity, language and culture, but not nationality, are becoming the touchstones of personal identity).

4. See J.O. IRUKWU, NigERIA AT CROSSROADS: A NATION IN TRANSITION 284 (1985):

Africa has suffered so much greatly as a result of tribalism. Wars have been fought and thousands of lives lost as a result of tribal and ethnic conflicts; important economic institutions that would have transformed national economies have been killed due to tribal differences; great African industrialists and scientists have had their careers ruined or programmes frustrated or destroyed because they belong to the 'wrong' ethnic group in relation to those in power at the material time.

5. Jerome Wilson, Ethnic Groups and the Right to Self Determination, 11 CoNN. J. INT'L L. 433, 436 (1996) ("Ethnic identification seems to be driven by the desire, on the one hand, for psychological security and self-esteem, and, on the other hand, for material gain. The desire to have security, self-esteem, and material gain are strongest when common social goods are threatened."). 
masses' resolve to rally around the leaders of their ethnic groups. ${ }^{6}$ Whether motivated by fear or by a desire to dominate others, the resurgence of ethnicity in the political process has destroyed many African nations and mortally wounded others. ${ }^{7}$ Failed $^{8}$ and failing states, ${ }^{9}$ internecine wars, bitter and violent struggles for power, ${ }^{10}$ and massive human rights violations in Africa are in large part traceable to ethnic rivalries. "

African nations' attempts to navigate through the thicket of ethnic tensions and to promote national unity have been consistently undermined and ultimately thwarted by political elites' inability to subordinate ethnic sentiments to the overriding interest of the nation. ${ }^{12}$ Ethnic loyalties impede

6. An ethnic group has been described as a group of persons who recognize themselves as members of a group that has very particular characteristics, including: (1) persistence over time, (2) shared religious, ideological, and other cultural features, (3) specific forms of communication and interaction, and (4) mutual self-identification as a category distinct from others. See Gwendolyn Mikell, Ethnic Particularism and the Creation of State Legitimacy in West Africa, 4 TULSA J. COMP. \& INT'L L. 99, 103 (1996) (citing FREDRIK BARTH, ETHNIC GROUPS AND BOUNDARIES (1969)).

7. For an account of troubled and collapsed states in Africa, see generally, COLLAPSED STATES: THE DISINTEGRATION AND RESTORATION OF LEGITIMATE AUTHORITY (I. William Zartman ed., 1995) [hereinafter COLLAPSED STATES].

8. Failed states are those whose governments have collapsed or have degenerated towards anarchy. See Gerald Helman \& Steven Ratner, Saving Failed States, 89 ForeigN POL'Y 1, 3 (1992). An example of a failed state is Liberia. In 1990, the country collapsed following the attack of Samuel Doe's government by rebel forces led by Charles Taylor. Others include Somalia, which collapsed in 1991 when rebel forces overran the government of Mohammed Said Baire, and Rwanda, which collapsed in 1994 after the President Juvenile Habyarima, a Hutu, was killed in a plane crash.

9. Failing states are those whose central governments lack sufficient authority to maintain law and order within their boundaries. The legitimacy and authority of these states have been considerably eroded by social, economic, and political upheavals. Failing states include Nigeria, Sudan, Zaire, Ethiopia, Kenya, and Chad.

10. General Olusegun Obasanjo, former Head of State of Nigeria (1976-79), observed that "the continent is a theatre for more endemic deadly conflicts than any other region of the world. These have had devastating effects on African societies." CONFLICT RESOLUTION IN AFRICA (Francis Deng \& William Zartman eds., 1991).

11. For a discussion of civil strife, civil wars, and state collapse in Africa, see THE FAILURE OF THE CENTRALIZED STATE: INSTITUTIONS AND SELF GOVERNANCE IN AFRICA (James Wunsch \& Dele Olowu eds., 1990) Thereinafter THE FAILURE OF THE CENTRALIZED STATE]. For human rights violations under Nigeria's military regimes, see 1993 U.S. DEP'T of STATE DiSPaTCH, Nigerian HuMAN RIGHTS PRACTICES (1994) (setting forth an account of human rights violations in Africa) [hereinafter NIGERIAN HUMAN RIGHTS PRACTICES].

12. Howard French, Can African Democracy Survive Ethnic Voting, N.Y. TIMES, Mar. 17,1996 , at EA (stating that the emotional pull of allegiances based on tribe, language, and religion remains far stronger than appeals based on policies and platform); LARRY DIAMOND, CLASS, ETHNICITY AND DEMOCRACY IN NIGERIA: THE FAILURE OF THE FIRST REPUBLIC 41 (1988) (noting that from the first significant elections in 1951, to the final fraudulent and brutal confrontations in 1964 and 1965, the regional classes used ethnicity as an electoral weapon against each other and against low class challengers from below). 
the democratic process in two ways: (1) they often promote capricious conduct by the dominant ethnic group, which often employs repressive policies to retain political control; and (2) they heighten minority ethnic groups' fear of exclusion and ultimately engender disloyalty to the nation. Ethnic distrust has infested every aspect of the civil society, including revenue allocation, education, and distribution of social amenities. ${ }^{13}$ The political process inevitably turns into a squabble about which ethnic group gets what reward. There are no reasoned debates or structured approaches to national issues, just balancing ethnic concerns. Ethnic hostilities will continue to serve as a countervailing force to national unity unless Africa devises a strategy that will meaningfully and effectively eliminate or relieve the problems that promote ethnic rivalries. ${ }^{14}$

Efforts at restoring social order in Africa have focused almost exclusively on the establishment of constitutional democracy. The calls for democracy as a panacea to Africa's problems proceed on the assumption that a democratically elected government will observe the rule of law, respect citizens' rights, and, more fundamentally, make governments accountable to the masses. A cursory examination of Africa's political landscape reveals that most attempts at setting up a constitutional democracy have succumbed to powerful destabilizing centrifugal ethnic forces, thereby creating a continent without any real prospects of peace. ${ }^{15}$ Ethnic forces have also overwhelmed economic and social policies designed to elevate the moral and material well-being of citizens. The failure of democracy has led to civil war and endless military intervention in the political process with attendant massive human rights violations, corruption, and mismanagement. ${ }^{16}$ Consequences of such failures are so ominous that continued replication of similar efforts is morally unacceptable.

This paper focuses on Nigeria to illustrate the impact of ethnicity on the search for a durable social order in Africa. Nigeria, one of the wealthiest nations in Africa, is at a crossroad. Once touted as the "most stable African nation, $" 17$ Nigeria has been plagued by intractable ethnic

13. For a detailed analysis of the controversy surrounding revenue allocation in Nigeria, see Attorney General of Bended State v. Attorney of the Fed'n, 2 N.C.L.R. 1 (1982).

14. Professor Akande identifies six basic problems in Nigeria: fear of the predominance of one state over others, overcentralization of powers, lack of consensus politics and government based on community of interests, absence of truly integrative national political parties, non-establishment of the principle of public accountability for office holders, and inequitable system of revenue allocation. See Jadesola O. Akande, Constitutional Development in Nigeria, in The Challenge of THE Nigerian NATION 27 (1985).

15. See THE Fallure of the CENTRALIzed STATE, supra note 11; DaNIEl Horowitz, ETHNIC GROUPS IN CONFLICT (1985).

16. See supra text accompanying notes 11 and 12 .

17. ARTHur A. Nwankwo \& Samuel U. Ifejika, Biafra: The Making of a Nation 125 (1972) (noting that Nigeria was expected to be "Africa's bastion of democracy and 
tensions and rivalries, and the country is now degenerating toward anarchy.18 After thirty-six years, Nigeria has been characterized by ethnic rivalries that have resulted in a traumatic thirty-month civil war, ${ }^{19}$ six military coups, ${ }^{20}$ an unsuccessful experimentation with various constitutional models, ${ }^{21}$ and massive human rights violations. ${ }^{22}$ As a result, Nigeria represents the faded hopes, broken promises, and tantalized aspirations of a people in search of a durable social order and economic empowerment. ${ }^{23}$

Contrary to the views of many Western nations that democracy

stability").

18. A June 1994 report of the U.N. Development Program lists Nigeria "as among countries in danger of joining the world's list of failed states because . . . of disastrous social upheavals and explosions." Paul Lewis, U.N. Lists Four Nations at Risk Because of Wide Income Gaps, N.Y. TIMES, June 2, 1994, at A6.

19. The civil war lasted from 1967 to 1970 . For a detailed account of the civil war, see JoHN DE ST. JORRE, THE NIGERIAN CIVIL WAR (1972); KEN SARO-WIWA, ON A DARKLING Plain: AN ACCOUNT OF THE NigerIaN CIVIL WAR (1989); NTIEYONG U. AKPAN, THE STRUGGLE FOR SECESSION, 1967-1970 (1976).

20. The 1966 coup attempt marked the beginning of military involvement in Nigerian politics. The military, previously insulated from politics and subordinate to civilian authority, suddenly became a key player in the political process. Having tasted political power, the military found it increasingly difficult to accept civilian authority. See Paul Adams, Reign of the General, AFR. REPORT, Nov.-Dec. 1994, at 27-28 (commenting that the primary role of the Nigerian military has become political rather than military after 24 years of army rule out of the 34 years since independence). Between 1966 and 1996, there were five successful coups. In July 1966, General Gowon seized power and ruled until July 29, 1975, when General Mohammed seized power in a bloodless coup. General Mohammed ruled for 200 days until he was assassinated. On December 31, 1983, General Buhari seized power and ruled until he was ousted on August 7, 1985, in a coup led by General Babangida, who ruled Nigeria until August 26, 1993. On November 17, 1993, General Abacha, the current head of state, seized power from the interim national government of Chief Shonekan. Nigeria also experienced coup attempts in January 1966, February 1976, and April 1990. Two other coup plots were uncovered and circumvented in 1985 and in 1994. For an accurate chronicle and history of coups and attempted-coups in Nigeria, see Factsheet on Coup Precedents in Nigeria, AGENCE FRANCE-PRESSE, Mar. 10, 1995, available in 1995 WL 777542.

21. Nigeria has experimented with two constitutional models since attaining independence in 1960: a parliamentary system of government from 1960 to 1966, and a presidential system between 1979 and 1983.

22. For human rights violations in Nigeria, see U.S. DEP'T OF STATE, CoUNTRY REPORT ON HUMAN RIGHTS PRACTICES FOR 1994, at 287 (1995); A. OlLANREWAJU, THE BAR AND THE BENCH IN DEFENSE OF RULE OF LAW IN NIGERIA (1992); LAWYERS COMMITTEE FOR HUMAN RIGHTS, IN DEFENSE OF RIGHTS: ATTACKS ON LAWYERS AND JUDGES (1994); Nigerian HumaN RIGHTS PRACTICES, supra note 11.

23. This is not peculiar to Nigeria. The African political landscape is replete with crumbled, crumbling, and chaotic nations groping for solutions to civil strife and ethnic conflicts. The rate and frequency of reforms in Africa led Colin Legum to describe this era as the second independence of the continent. See Colin Legum, The Coming of Africa's Second Independence, 13 WASH. Q. 129 (1990). 
provides an appropriate framework for preserving social order in Nigeria, ${ }^{24}$ this paper argues that the most efficacious, and perhaps the only viable way to preserve order in Nigeria is to partition the nation. ${ }^{25}$ The goals of resolving ethnic tensions and successfully implementing democracy in Nigeria entail wholesale changes in attitudes and social practices. These changes seem very unlikely in the near future. Preserving social equilibrium in Nigeria through constitutional democracy is an unwinnable battle-a task rendered more difficult by ethnic rivalries as well as by a conspicuous absence of democratic culture. The uneasy ethnic groups that comprise Nigeria have clearly and repeatedly demonstrated their unwillingness to subordinate ethnic loyalties to the interest of the nation. ${ }^{26}$ The intense ethnic rivalries and aggressive ethnic identification among the political elites render democracy an inherently unworkable proposition. ${ }^{27}$ Democracy can never work if "political competition only generates patterns of political mobilization and conflict which threaten the very integrity of the nation itself. ${ }^{28}$ The deep-seated ethnic distrust and rivalries provide an inhospitable environment for the implementation of democracy. ${ }^{29}$ Political leaders who manipulate ethnicity to gain political advantage often find themselves overwhelmed by the ethnic sentiments they have engineered. Far too often, ethnic rivalries result in weakened and ineffectual leadership, as citizens rarely accept or submit to the authority of leaders from different ethnic groups. ${ }^{30}$ Pervasive ethnic irredentism has reached the point where the minimum conditions necessary for democracy no longer exist in most

24. Western nations frequently use democracy as the yardstick for evaluating a nation's legitimacy. Consequently, the United Nations devotes considerable resources and time to assisting troubled nations establish democracy. For a detailed study of the United Nations' efforts in that regard, see Douglas Lee Donoho, Evolution or Expediency: The United Nations' Response to the Disruption of Democracy, 29 CORNELL INT'L L.J. 329 (1996).

25. William Schroeder, Nationalism, Boundaries and the Bosnia War: Another Perspective, 19 S. ILL. U. L.J. 153, 161 (1994) ("Only after an ethnic group has achieved selfgovernment within secure and definite boundaries is democracy likely to take root.").

26. For a rich study of the various ethnic groups in Nigeria, see JAMES COLEMAN, NigERIA: BACKGROUND TO NATIONALISM 15 (1958).

27. Michael Lind, In Defense of Liberal Nationalism, 73 Foreign AFF. 95 (commenting that the evidence is overwhelming that democracy does not work in societies divided along linguistic and cultural lines).

28. RICHARD A. JOSEPH, DEMOCRACY AND PREBENDAL POLITICS IN NIGERIA: THE RISE AND FALL OF THE SECOND REPUBLIC 185 (1987).

29. For a detailed analysis of ethnic conflicts in Nigeria, see NNOLI OKWUDIBA, ETHNIC POLITICS IN NIGERIA (1978); John Paden, Communal Competition, Conflict and Violence in Kano, in Nigeria: Modernization AND the Politics of Communalism 113-44 (Melson \& Wolpe eds., 1971).

30. Robert Jackson, Juridical Statehood in Sub-Saharan Africa, 46 J. INT'L AFF. 1 (1992) (stating that many post-colonial states in Africa lack an independent political organization with enough authority and power to govern a people and territory; in other words, they lack the essential requirements of empirical statehood). 
African states. ${ }^{31}$ Neither the political elites who seek power nor the masses are willing to subordinate ethnic loyalties to the overriding interests of the nation. ${ }^{32}$

This paper contends that seeking political stability in Nigeria through constitutional democracy is an unattainable ideal, an illusory notion sedulously promoted by dominant ethnic groups and their foreign allies. Democracy can never resolve the deep-seated ethnic distrust and rivalries in Nigeria, currently kept within bounds by the ruling military junta. ${ }^{33}$ Democracy is typically effective in countries where citizens have internalized democratic values and political elites observe the rule of law. ${ }^{34}$ Constitutional democracy in Nigeria has always been a multi-headed monster with different faces: flagrant violation of the rule of law; brutal suppression of political opponents; exclusion of minorities from the governance process; and manipulation of the electoral process by ethnic entrepreneurs masquerading as nationalists. ${ }^{35}$ Constitutional democracy cannot obliterate

31. Most definitions of democracy draw heavily from ROBERT DAHL, POLYARCHY: PARTICIPATION AND OPPOSITION (1971). Dahl states that “a key characteristic of a democracy is the continuing responsiveness to the preferences of its citizens, considered as political equals." Id. at 1 . To achieve the level of accountability described by Dahl, certain conditions must exist: freedom to form and join organizations, periodic free and fair elections, and the right to vote. See generally POLITICS IN DEVELOPING COUNTRIES: COMPARING EXPERIENCES WITH DEMOCRACY 7 (Larry Diamond et al. eds., 1991), eloquently describing political democracy as

meaningful and extensive competition among individuals and organized groups ... for all elective positions of government power, at regular intervals and excluding the use of force; a highly inclusive level of political participation in the selection of leaders . . . and a level of civil and political liberties-freedom of expression, freedom of press, freedom to form and join organizations.

32. Makau Wa Mutua, Redrawing the Map Along African Lines, Boston Globe, Sept. 22,1994 , at 17 (noting that citizens as a whole lack an instinctual bond to the state; hence, those who become rulers pillage it in league with members of their ethnic group and resort to massive human rights violations to repress those they have excluded).

33. JOHN MACKINTOSH, NIGERIAN GOVERNMENT AND POLITICS 619 (1966) (noting that democracy in Britain and the U.S. was never intended and has never managed to settle the range of questions, the whole position of tribes, or the domination of the country by one or two areas).

34. Professor Wing correctly observed that "[d]emocracy is based in part on constitutionalism, the creation of a culture in which the governing document is followed as a charter for the exercise and limit of official power." Adrien Wing, Towards Democracy in a New South Africa, 16 MICH. J. INT'L L. 689, 690 (1995) (book review).

35. David Peterson is probably correct in his assessment of the workability of democracy in Africa. He states:

Africa is not ready for democracy. Africans neither want it nor understand it. What Africa really needs is food, stability, and development. Democracy is just another fad-another western imposition. Little has changed in Africa; the dictators are still in place, corruption and human rights abuse are the norm. Democracy only gives rise to tribalism and war; it hinders economic 
the legacy of ethnicity. If this continues, there will be neither an end to ethnic strife nor a dearth of politicians eager to exploit ethnicity. ${ }^{36}$ More importantly, there is no guarantee that a new civilian administration will not imitate its corrupt, inept, and abusive predecessors. ${ }^{37}$ Moreover, the option of restoring equilibrium through democracy has long expired. It was fatally wounded by a selfish, insincere, ambitious, and often ethnically-motivated military that lacks a culture of subordination to civilian authority. ${ }^{38}$ The military's litany of broken promises to restore civilian administration has irredeemably destroyed citizens' faith in the democratic process. ${ }^{39}$

Nigeria is in this precarious position by imperial design, and the position is rendered more intractable by Nigeria's inaction and perhaps complicity..$^{40}$ We cannot continue to allow boundaries arbitrarily drawn by colonial masters to imperil social equilibrium and political stability in Nigeria. ${ }^{41}$ However unpalatable it might appear, Nigerians must

development. Africa is still too poor and illiterate for democracy. The entire continent is strategically insignificant anyway. All the foreign aid to Africa only makes the situation worse. At best, democracy will take decades to emerge.

David L. Peterson, Debunking Ten Myths About Democracy in Africa, 17 WASH. Q. 129 (1994).

36. Hurst Hannum, Minority Rights, Introduction, 19 SPG FLETCHER F. WORLD AFF. 1,4 (1995) (noting that democracy is not a panacea for resolving competing ethnic demands).

37. For a vivid account of the misdeeds of the last civilian administration, led by Alhaji Shehu Shagari from 1979-1983, see WOLE SOYINKA, THE OPEN SORE OF A CONTINENT: A PERSONAL NARRATIVE OF THE Nigerian CRISIS 61-74 (1996).

38. The formidable obstacle posed by Africa's military in the continent's search for constitutional democracy was poignantly summarized by William Foltz. He writes that "in most of Africa, government has been synonymous with the military. Today, as civilian administrations struggle to create democratic traditions, their toughest task may be to convince their armies to accept secondary status and maintain political neutrality." William J. Foltz, Democracy: Officers and Politicians, 38 AFR. REP. 65.

39. Sakah Mahmud, The Failed Transition to Civilian Rule in Nigeria: Implications for Democracy and Human Rights, 40 AFR. TODAY 87, 91 (1993) (noting that the frequency with which Nigerians have been disappointed with the process of democratization is enough to create a negative and perhaps lasting feeling of hopelessness and disbelief that the cycle of military rule will be permanently broken).

40. Dr. Mutua places the blame for state failures in Africa on colonial policies, especially the grouping of diverse ethnic groups under one nation. He states:

The ethnic plurality, and, in some cases, the duality of the state, have finally caught up with post-colonial Africa. Absent cold war or neo-colonial international guarantees to client states, the colonial state is nothing if not a house of cards. Its ethnic configuration, an integral legacy of colonization, is a major factor in its failure.

Makau Mutua, Why Redraw the Map of Africa: A Moral and Legal Inquiny, $16 \mathrm{MICH}$. J. INT'L L. 1113, 1147 (1995) (footnotes omitted).

41. Joseph Hummer, A Generation of Failure, NEwSwEEK, Aug. 1, 1994, at 32 (commenting that much of Africa is still paying the price of colonialism: in the late 19th 
acknowledge that there is no way of encouraging warring, distrustful, and often intolerant ethnic groups to coexist harmoniously. We must look beyond the surface and appreciate the intense inter-ethnic hostilities simmering beneath the façade of calm held out by the Nigerian military rulers and their civilian allies. ${ }^{42}$ The truth is that Nigeria is in deep trouble, roiled incessantly by ethnic rivalries and lack of loyalty to the nation. Unchecked, these clearly visible signposts of anarchy will consume the nation. ${ }^{43}$ The genocide in Rwanda, the chaos in Somalia, and the pogrom that led to the Biafran failed secession attempt are merely signposts on the road to destruction that Nigeria will surely travel should it remain indifferent to ethnic conflicts.

The message to the proponents of "one Nigeria" 44 is simple but urgent: pursue your vision of one Nigeria and allow the nation to continue its downward spiral toward anarchy or act decisively and stanch the blood that flows from mortal wounds inflicted upon the nation by warring ethnic groups. Promoting the rule of law and preserving social equilibrium would be best achieved through redrawing boundary lines. Granting homogenous ethnic groups a nation of their own would reduce human rights violations and

century, European imperialists carved up the continent without regard to natural tribal or political borders).

42. Military rulers frequently take out self-promoting advertisements in newspapers to reassure the public that all is well in Nigeria. The ruling Abacha regime has retained American public-relations consultants to help polish its image abroad.

43. Larry Diamond, an authority on Nigeria, eloquently discussed in his testimony before the United States House of Representatives' International Relations Committee, SubCommittee on Africa, the warning signs of political and social decay and correctly states that these signs are increasingly evident today in Nigeria.

States do not collapse all of a sudden, out of the blue. The process is anticipated by numerous signs of decay. Political institutions lose capacity, flexibility, and legitimacy. Social and economic problems mount in the face of state corruption and ineptitude. Crime and violence flourish and fear proliferates. State authority withers and people retreat into formal arenas. Political power and national wealth become monopolized by an increasingly narrow elite, which substitutes force for dialogue, bargaining and legitimate authority. Mass constituencies become more and more alienated, angry and embittered. Contending elites manipulate ethnic, regional, and religious cleavages in the struggle for power and incidents of deadly conflict escalate in number and scale . . . . Civil society fragments and recedes. Every type of institutional glue that binds diverse cultures, regions, classes and factions together into a common national framework gradually disintegrates.

Preventive Diplomacy for Nigeria: Imperatives for U.S. and International Policy: Testimony Before the Subcomm. on Africa of the House Comm. on International Relations (Dec. 12, 1995) (statement of Larry Diamond), available in 1995 WL 13415408.

44. "One Nigeria" is a slogan coined during the Nigerian Civil War (1967-1970) to denote the indivisibility of Nigeria. Successive regimes remain adamantly committed to the notion of one Nigeria. 
insure that citizens participate in the governing process. Nigeria has very little choice in the matter: partition amicably now or do it at great cost after bitter strife..$^{45}$ Partition is the only realistic way for Nigeria to avoid the devastation, misery, and agony suffered by failed African states like Rwanda, ${ }^{46}$ Somalia, ${ }^{47}$ and Liberia. ${ }^{48}$ Partition is the most creative and effective way of numbing ethnic tensions in Nigeria. The successful extraction of Eriteria from Ethiopia and the peaceful Balkanization of the former Soviet Union and Yugoslavia provide paradigms for the rest of Africa. ${ }^{49}$

Part II of this paper traces Nigeria's search for constitutional democracy. Part III examines the impact of ethnicity on the political process. Part IV reviews three strategies for combatting the evils of ethnicity in Nigeria. These strategies include enforcing legal rules, attacking the social forces that promote ethnicity, and partitioning the nation.

\section{The SEARCH For CONSTITUTIONAL DEMOCRACY IN NIGERIA}

\section{A. Historical Perspective}

Before the coming of the British, the geographical area presently known as Nigeria consisted of different ethnic groups. ${ }^{50}$ Each group was largely homogenous and was bound by shared religion, customary values, mores, and ethos. ${ }^{51}$ There were three dominant ethnic groups in Nigeria: the Hausas in the North, ${ }^{52}$ the Yorubas in the West, ${ }^{53}$ and the Ibos in the

45. See generally Mutua, supra note 40 , at 1113. Mutua believes that a bleak future confronts Africa unless the boundary lines are peacefully and voluntarily redrawn. He states that "foreign imposition of artificial states and their continued entrapment within the concepts of statehood and sovereignty are sure to occasion the extinction of Africa unless those sacred cows are set aside for now to disassemble African states and reconfigure them." Id. at 1118.

46. For a detailed analysis of the Rwandan crisis, see David Newbury, Irredentist Rwanda: Ethnic and Territorial Frontiers in Central Africa, 44 AFR. TODAY 2211, 2211-22 (1997).

47. For a brilliant analysis of the crisis in Somalia, see THE SOMALI CHALLENGE: From CATASTROPHE TO RENEWAL (Ahmed Samatar ed., 1994).

48. For a study of the ethnically-motivated violence in Liberia, see Stephen Ellis, Liberia 1989-1994: A Study of Ethric and Spiritual Violence, 94 AFR. AFFAIRS 165 (1995).

49. Michael Wrong, Ethiopia Buries the African Nation State: For the First Time a Region's Right to Secede is Laid Down in the Constitution, FIN. TIMEs, May 5, 1995.

50. For a detailed history of Nigeria, see ALAN C. BURNS, History OF NIGERIA (4th ed. 1948).

51. K.A. Busia, Africa IN SEARCH OF DEMOCRACY 30-31 (1967) (noting that precolonial African communities were held together because they inhabited a common territory, their members shared a tradition, real or fictitious, of common descent, and they were held together by a common language and a common culture).

52. See ColEman, supra note 26 , at 39 . The Hausas were bound by common language, 
East. ${ }^{54}$ Surrounding and within the perimeters of each of these three major ethnic groups were an array of minority ethnic groups. For example, Efik Ibibios, Ijaws, and the Ekoi-Yakuri surrounded the Ibos. The Yorubas contained the Edos, Urhobos, and Ijaws, while the Hausa had the Kanuris, Tivs, and the Nupes.

Something more than geography separated these ethnic groups; there were profound cultural, religious, and linguistic differences as well. ${ }^{55}$ Yet the colonial administrators, for political and economic reasons, brought all the ethnic groups together and created one country called Nigeria. ${ }^{56}$ This was done without any concern for the inhabitants and pre-existing relationships between the ethnic groups..$^{57}$ The transition from autonomous

history, and strong fidelity to Islam. At the beginning of the 19th century, during the holy war of 1804, the Muslim Fulanis led by Usman Dan Fodio conquered the Hausa Kingdom. Aided by an extensive military machine and the Islamic religion, Usman Dan Fodio established a centralized administrative structure with strong emphasis on class hierarchy and loyalty of subjects to constituted authority. The Emirs governed different segments of the area that constituted Northern Nigeria. The Emirs were assisted by other officials, including: the Waziri, directly accountable to the Emir; the Dagga, in charge of internal security; and the Alkali, in charge of judicial functions. For a detailed history of the Hausas, see E.D. MOREL, Nigeria: Its People AND Problems 99-102 (1968); Notes ON THE TRIBES, Provinces, EMIRATES AND STATES OF THE NORTHERN PROVINCE OF NigERIA (C.L. Temple ed,, 1965); POlly Hill, Rural Hausa: A Village aNd a SETting (1972); Charles OrR, The MAKING OF NORTHERN NIGERIA (1965).

53. See A. AKInOYe, Revolution and Power Politics In YoRUBa LaNd 1940-1983, at 5-6 (1971). The Yorubas consisted of loosely organized kingdoms that prided themselves on being able to ward off Fulani incursions. The kingdoms shared a common religion and were linked together by a common ancestry. The Yorubas had a highly structured organizational hierarchy with chiefdoms headed by the Alafin, assisted by a prince and a Bashorun or chief minister. Yoruba politics was highly participatory: dynastic and social groups were recognized as interest groups. Their political organization was pyramidal, and the social groups were contra-positive in a series of dyadic relationships characterized by conflict and competition. See ROBERT SMITH, KInGDOMS OF THE YorUBA (3d ed. 1988).

54. See William EVANS-SMItH, Nigeria: A CounTry STUdY xvi (1982). The Ibos consisted of autonomous villages united by common religion, culture, and political structure. The Ibos, unlike the Hausas and Yorubas, had a completely different political apparatus. The Ibos consisted of several fragments made up of more than 200 subgroups. These subgroups consisted of clusters of culturally and linguistically related communities but were politically cohesive. See also Kalu Ezera, Constitutional DeVElopment in Nigeria 8-9 (1964) (noting that the Ibos had no indeginous overall political authority around which their loyalty was crystallised).

55. B.O. NWABUEZE, A CONSTTTUTIONAL History OF NigERIA 129-30 (1982) (stating that the Muslim North and the population of the South are quite different peoples, separated not just by tribal and language differences, but also by those of race, culture, religion, social and political organization, economy and even geography).

56. DIAMOND, supra note 12 (noting that, like other colonial powers, the British carved arbitrary and artificial boundaries around their two Nigerian protectorates, merging people with few or no common cultural or political bonds).

57. Chris M. Peter, The Proposed African Court of Justice-Jurisprudential, 
tribal communities to a nation-state, hurriedly forced on most African nations by the colonial administration, remains the major obstacle to constitutional democracy in Africa. ${ }^{58}$ Though Nigeria has acquired many attributes of a nation-state, political elites have been unable to forge a collective sense of identity and unity among several ethnic groups that comprise the nation. ${ }^{59}$ The area known as Nigeria is not really a unified country; it comprises multiple ethnic groupings, identified by ethnic loyalties and lacking a common sense of nationhood. Nigeria's failure to forge a sense of unity and nationhood among the various ethnic groups has been sufficiently documented. Chief Obafemi Awolowo, former Premier of the defunct Western Region and a Presidential candidate in the 1979 and 1983 general elections, stated that "Nigeria is not a nation. It is a mere geographical expression. There are no 'Nigerians' in the same sense as there are 'English,' 'Welsh,' or 'French.' The word 'Nigerian' is merely a distinctive appellation to distinguish those who live within the boundaries of Nigeria from those who do not. ${ }^{260}$ Tafawa Balewa, former Prime Minister of Nigeria during the first republic between 1960 and 1966, observed that "[s]ince the amalgamation of the southern and northern provinces in 1914, Nigeria has existed as one country only on paper. It is still far from being united." $" 61$

Ethnic rivalries in Nigeria are not rooted in history; they are recent struggles to control the machinery of the modern state called Nigeria. ${ }^{62}$ Lawrence Friedman states that "ethnic identity is not natural or inborn, nor the product of ancient tradition; instead it is socially constructed. It is, in fact, one of the bastard children of modernization." ${ }^{63}$ In pre-colonial Nigeria, ethnic rivalries and hatreds were small because each ethnic group rarely ventured beyond its boundaries. If they did, they engaged in peaceful,

Procedural, Enforcement Problems and Beyond, 1 AFR. J. PEACE \& HUM. RTS. 117, 124-25 (1993) (" $[A] t$ the Berlin Conference, Africa was regarded as terra nullius, subject to the possession of the European power exercising effective authority. They never took any account that there were people of vastly different backgrounds and cultures living on the continent.").

58. BUSIA, supra note 51, at 171 (arguing that the tribal solidarity of the past invades the present-creating problems of political organization for the states of Africa-and has been a source of tension and instability).

59. OlUWOLE OdUMOSU, THE NIGERLAN CONSTITUTION: HISTORY AND DEVELOPMENT 17 (1963) (noting that marked differences in language, religion, custom, and culture could not be obliterated by the mere fact of amalgamation).

60. Obafemi Awolowo, Path to Nigerian Freedom 47-48 (1947).

61. NWANKWO \& IFEIKA, supra note 17 , at 30.

62. DLAMOND, supra note 12, at 290 (noting that ethnic conflict was not deeply rooted in Nigerian history; different tribes exchanged goods amicably more often than they warred, and, in any case, they were less centralized in scale and much less regular in their external contacts).

63. Lawrence Friedman, Introduction: Nationalism, Identity and Law, 28 IND. L. REV. 503, 503 (1995). 
productive, and mutually beneficial activities, like trading. Each ethnic group placed a tremendous premium on survival and rarely engaged in conduct that disrupted social equilibrium.

Severe ethnic polarization in Nigeria is traceable to the coming of colonialism. More specifically, a cause of this ethnic polarization is especially misguided colonial policies that have encouraged ethnic differences. ${ }^{64}$ Aniagolu, a retired justice of the Nigerian Supreme Court, observed:

The colonial rule, while not being all negative, poignantly left in its wake disaster and desolation. In order to rule Nigeria, the British had to adopt certain strategies and principles. They not only adopted the wise political principle of "indirect rule" but also the vicious, divisive policy of "divide and rule." Instead of emphasizing and harnessing the richness of our cultural diversities, the British exacerbated and pitched our differences. While the ethnic groups were at each others' throats, the British reaped their economic and political harvests. ${ }^{65}$

The first colonial policy that encouraged ethnic loyalties is the forcible grouping of radically different ethnic groups into one nation. The creation of a nation-state and the attendant modernization transformed the society from homogenous and autonomous, bound by shared cultural values, to a highly fragmented society in which citizens were forced to re-adjust to an alien civil order. ${ }^{66}$ The colonial civil order undermined customary values and ethos that formerly preserved equilibrium in the society. It also considerably weakened the native political apparatus, thus rendering the administrative machinery too ineffective to generate the loyalty and support

64. DiAMOND, supra note 12, at 28 (noting that colonial rule failed to develop institutions that could have integrated Nigeria's common cultural, social, and political symbols and structures).

65. A.N. Aniagolu, Keeping Nigeria One Through Visionary Constitutional Engineering: Philosophy Behind Some Provisions of the 1989 Constitution, 21 CAP. U. L. REV. 1033, 1034 (1992); Mikell, supra note 6, at 104, states:

Many of the present situations of ethnic conflict and political chaos in West

Africa have their roots in distorted processes of political competition that began with western colonialism approximately one hundred years ago. What we now call "ethnicity" was very much the outcome of the nineteenth century period of colonial conquest when western metropolitan or settler groups used force to divide, conquer, and then politically subjugate the African indigenous populations. In essence, colonial policy subverted the political and cultural legitimacy of both strong and weaker ethnic groups.

66. Mikell, supra note 6, at 105 ("colonial policies forced individuals to respond to norms which promoted individual or western interests, often to the exclusion of ethnic communal interests"). 
of the citizens. The re-adjustment process proved especially traumatic as powerless inhabitants painfully watched the colonialists discard, discredit, and, at times, desecrate traditional institutions and customs that preserved order in the society. ${ }^{67}$ The ruthless and Machiavellian manner in which colonial masters pursued their policies, the flagrant disregard of customary values, and contempt for the traditional political apparatus alienated vast segments of the population. ${ }^{68}$ Unable to exert themselves, citizens retired to their ethnic groups to find solace and form coalitions to ward off imperialism. Finding solace among citizens united by disgust for the imperial masters ultimately generated ethnic consciousness and resulted in cleavages that no government in Nigeria has overcome.

Ethnic rivalries were not so pronounced during the colonial era because the colonial administration's reputation for ruthlessness acted as a restraining influence on the ethnic warlords. ${ }^{69}$ Moreover, the ethnic groups had nothing to fight over since the colonial powers maintained "exclusive control over the political and economic resources of their colonies."70 When the colonial administration left, ethnic groups engaged in a fierce battle with each other to control the machinery of the state. ${ }^{11}$ Freed from the pangs of despotism and dictatorship, ethnic groups became interested in acquiring political power and the economic resources that go with it. ${ }^{72}$ The battle intensified as

67. Id. at 106 (noting that under British rule, cultural values were assailed. Pride in the welfare of the people was frowned upon and was derisively described as "native." By this, the dignity of the human person based upon cultural awareness was devalued).

68. Mutua, supra note 40 , at 1137 , states:

The newly contrived state represented, for many Africans, the physical symbol of the loss of independence and sovereignty over their societies. The manner in which it was created, after long periods of resistance, the way it was governed, and the purpose for which it was brought into existence, namely the exploitation of both natural and human resources, were a grim reminder of the luxuries of self-governance. Colonial policies were harsh and brutally implemented. Such practices did little to endear Africans to the state or develop a loyalty towards it.

69. George Carew, Development Theory and the Promise of Democracy: The Future of Post Colonial African States, 40 AFR. TODAY 31, 32 (1993) (stating that colonial administration kept its disparate ethnic groupings together through coercion and manipulation).

70. Wilson, supra note 5 , at 447.

71. Francis Deng, Africa and the New World Dis-Order: Rethinking Colonial Borders, BROOKINGS REV., Spring 1993, at 34 (noting that because colonial institutions had divested the local communities and ethnic groups of much of their indigenous autonomy and sustainable livelihood, and replaced them with a degree of centralized authority and dependency on the welfare state system, once control of these institutions passed on to the nationals at independence, the struggle for control became unavoidable).

72. Blood and Earth, ECONOMIST, Sept. 23, 1995, at 17. Describing the struggle for power that followed the end of colonialism, the article states: under despotism or colonialism . . . it did not matter much whether frontiers reflected ethnic reality. . . . Now in sudden liberty, it is easy to persuade people 
the state became increasingly identified as the purveyor of social amenities. ${ }^{73}$ The state, especially the political process, became a battleground for ethnic groups bent on securing greater benefits for themselves. ${ }^{74}$

The second colonial policy that intensified ethnic cleavages was the decision to treat the North and South as two separate entities. This policy sowed seeds of ethnic distrust that blossomed over the years. Though the British recognized a single political entity called Nigeria, they rarely ruled Nigeria as a single nation. In 1900 , the British proclaimed two separate protectorates, North and South, for Nigeria. ${ }^{75}$ They established different administrative structures for each protectorate: they ruled the North through indirect rule, i.e., through traditional rulers, ${ }^{76}$ and they administered the South directly. ${ }^{77}$ Though they formally amalgamated the two protectorates in 1914, the British continued to rule each segment differently. ${ }^{78}$ In 1939 , the division of southern Nigeria into eastern and western regions coincided with ethnic boundaries: the West comprised predominantly of Yorubas and the East comprised of Ibos. All three regional governments were selfgoverning and functioned as autonomous organs of government. ${ }^{79}$

The deliberate encouragement of regional identities immensely contributed to ethnic schism in Nigeria ${ }^{80}$ By introducing and supporting regional governments, the colonial administration encouraged distinctive paths for each region that successive governments have been unable to negate. ${ }^{81}$ Failing to treat the nation as one political unit exacerbated ethnic

to care about those things a lot. Freed from a common yoke, peoples fight for

a prime position. No one wants to wind up a surrounded minority.

Id.

73. Mikell, supra note 6, at 108 ("Nigeria provides a classic case of conflict under conditions of scarcity where the state, after independence, has been seen as the major resource and is therefore the object of intense ethnic competition").

74. Some argue that the modernization process did not negate citizens' attachment to their ethnic groups. See David SMOck \& AudREY C. SMOCK, THE POLITICS OF PLURALISM: A COMPARATIVE STUdY OF LEBANON AND GHANA 3 (1975). The authors contend that "[e]vents in the last decade attest to the fact that communal attachments do not quietly wither away with the exposure to modernizing influences. Quite the contrary, modernization often creates the very conditions necessary for the incubation of strong communal identities and sets the stage for communal competition." Id.

75. COLEMAN, supra note 26 , at 54-56.

76. C.S. Whitaker, JR., The Politics of Tradition, Continuity and Change in NORTHERN NIGERIA, 1946-1966 (1970).

77. DIAMOND, supra note 12 .

78. $1 d$. at 26 (noting that even after formal amalgamation in 1914, the British continued to rule Nigeria as two countries).

79. MACKINTOSH, supra note 33, at 87-138 (1965).

80. Ali Mazrui notes that the encouragement, even creation, of ethnic loyalty and consciousness was a leading feature of British colonial rule. DIAMOND, supra note 12, at 28.

81. Adopting different administrative strategies for the different regions, indirect rule in the North, and direct rule in the South, generated resentment and hostility towards the 
differences and encouraged citizens to think about their own narrow ethnic group. ${ }^{82}$ Although Nigeria at various stages of political development emphasized nationhood, politicians since independence have invoked and exploited ethnic loyalties to cling to power. ${ }^{83}$ Since its inception as a sovereign nation, the largest and most populous African country has been plagued by grave problems: social unrest, lack of democratic culture, and economic mismanagement. In its thirty-seven year history as an independent nation, Nigeria's attempt to establish constitutional democracy has resulted in endless military coups, ${ }^{84}$ ethnic strife, and civil war. ${ }^{85}$ Different epochs of the country's bleak history require close scrutiny to enhance understanding of how Nigeria found itself in its current precarious position.

\section{B. $1960-1966$}

The attainment of independence in 1960 afforded an opportunity for Nigeria to control its destiny, to elevate the moral-being of its citizens, to raise the standard of living, and to foster unity among the various ethnic groups. ${ }^{86}$ More importantly, it afforded a unique opportunity for the nation to structure a government capable of addressing the concerns of a multiethnic and complex society in search of identity and modernization. Instead, Nigerian leaders chose to tread on familiar grounds and adopted the Westminster model of parliamentary democracy, which it practiced until the military intervention in $1966 .^{87}$

The years from 1960 to 1966 were ones of intense political unrest, rendered even more complicated by ill-prepared and insincere experimentation with constitutional democracy. In an attempt to fill the void created by the departure of colonial administrators, an array of ethnic

western political apparatus, and ultimately undermined attempts to forge nationalist ideals.

82. ColemaN, supra note 26 , at 210 (" $[t]$ he system of native administration was designed to foster love for and loyalty to the tribe").

83. W.B. Hamilton, The Nigerian Constitutional Conference of 1957, S. ATLANTIC Q., Fall 1958, at 491 (noting that all the leaders, and most minority groups, proclaim they are for a single, strong Nigeria, and it is the contradiction between their words and their actions that makes difficult the task of nationalism).

84. See supra note 20.

85. For an account of the civil war, see infra text accompanying notes 114-19.

86. INDEPENDENCE ACT § 1(2) (1960) (Nig.) states that as from October 1, 1960, Her Majesty's government in the United Kingdom shall have no more responsibility for the government of Nigeria or any part thereof.

87. For a detailed study of parliamentary democracy, see NwABUEZE, supra note 55, at 96-97 (noting that parliamentary democracy is characterized by four main features: the nominal position of the head of the executive and his separation from the effective head of government; the plurality of the effective executive which consists of cabinet members headed by a prime minister; the parliamentary character of the executive; and the responsibility of the ministers individually and collectively to the legislature). 
political leaders, irredentists, and untested power seekers violated all democratic norms to satisfy narrow parochial and ethnic interests. ${ }^{88}$ Additionally, the introduction of a multi-party system without an adequate infrastructure to promote democratic traditions inevitably resulted in group warfare. ${ }^{89}$ Parties were formed along ethnic lines. ${ }^{90}$ Political leaders were elected or supported not because of their policies or platforms, but because citizens perceived them as capable of protecting ethnic interests. Politicians played on ethnic sentiments of the largely unsophisticated citizenry, appealing to these sentiments whenever necessary to shore up political support. ${ }^{91}$ Political leaders who admirably forged a united front in the fight for independence soon underwent complete transformation; they turned into irredentists, tribal chieftains aggressively identifying with their ethnic groups and seeking to recruit their clansmen into government. ${ }^{92}$ The postindependence struggles revealed that the politicians never focused on the corporate welfare of Nigeria as the centerpiece of their opposition to colonial rule; rather, each was concerned with advancing ethnic interests. Political campaigns turned into an open season for destroying the fragile union. ${ }^{93}$ Politicians, unfamiliar with the restraints of the democratic process, used their powers to loot the national treasury, to enrich their allies, ${ }^{94}$ and to harass and intimidate innocent citizens, especially the opposition. ${ }^{95}$ Professor

88. Mikell, supra note 6 , at 100 ("[i]n Nigeria and Liberia, the 'ethnic entrepreneurs' have emerged, using cultural identities as tools to hijack the political process and garner control and resources within the state").

89. This phenomenon is common in most multi-ethnic African countries. President Yoweri Museveni of Uganda succinctly captured this phenomenon when he said that "multiparty systems were created by industrial societies and fit them because they tend to divide along fluid lines of class. But in pre-industrial African countries split vertically along rigid tribal lines, party competition can lead to group warfare." John Darton, Africa Tries Democracy, Finding Hope and Peril, N.Y. TIMES, June 21, 1994, at A8.

90. See infra text accompanying notes $215-44$.

91. Victor A. Oluronsola, The Politics of Cultural Subnationalism in AFRICA.

92. This phenomenon occurred in virtually all African countries. The machinery of government in newly emancipated African countries often "involved the incorporation of 'kith and kin' into ruling oligarchies and the exclusion of other groups from enjoying the prerogatives of power. This generated problems of ethnicity, clanism, regionalism, and religious bigotry." Jibrin Ibrahim, Political Exclusion, Democratization and Dynamics of Ethnicity in Niger, 41 AFR. TODAY 15 (1994).

93. JOSEPH, supra note 28, at 153 (1987) (noting that in "Nigeria [ ] party politics as a relentless struggle to procure individual and group benefits via the temporary appropriation of public offices eventually reduces the electoral process to a Hobbesian state-of-war").

94. Several commissions of inquiry empaneled to investigate allegations of impropriety found gross violations, abuse of power, and fraud in most government parastatals. The commissions also found that politicians viewed board appointments as rewards for loyal party supporters.

95. This appears to be a common phenomenon in most post-independent African nations. 
Ewelukwa provides an accurate characterization of the political process and the activities of politicians:

Most of the politicians were ignorant, small minded and parochial in outlook, and sought to make the Nigerian political arena congenial to their acquisitive, corrupt and undemocratic tendencies in life. By their methods, they made politics a rough, uncomfortable and hazardous pursuit for anyone, and in their frantic bid to enrich themselves illicitly out of public funds, they combined with certain professionals, independent contractors and even public servants to trample upon the rights and liberties of individuals and to make life difficult for the common man, thereby alienating his sympathy ... . In fact, all of them (politicians) directly or indirectly supported and encouraged improper dealings with public funds as well as aided and abetted gradual debasement of human rights and democratic values. ${ }^{96}$

Politicians, bent on retaining power, terribly upset whatever remained of social equilibrium in Nigeria. Elections, especially in the defunct western region, turned into warfare in which politicians brutally displayed their lack of respect for democracy and human dignity. Kirk-Greene aptly described the 1965 elections as "the ultimate debasement of the democratic process through chicanery and thuggery. ${ }^{n 77}$ The country was slowly degenerating

Jack Cope, in a fairly lengthy passage, clearly captured the African political elites' disrespect for the rights of fellow Africans:

Looking back from the perspective of the present, I think it can justly be said that, at the core of the matter, the Afrikaner leaders in 1924 took the wrong turning. Themselves victims of imperialism in its most evil aspect, all their sufferings and enormous loss of life nevertheless failed to convey to them the obvious historical lesson. They became themselves the new imperialists. They took over from Britain the mantle of the empire and colonialism. They could well have set their faces against annexation, aggression, colonial exploitation and oppression, racial arrogance and barefaced hypocrisy, of which they themselves were victims. They could have opened the door to humane ideas and civilizing processes and transformed the great territory with its incalculable resources into another new world. Instead they deliberatively set the clock back wherever they could. Taking over ten million indigenous subjects from British colonial rule, they stripped them of what limited rights they had gained over a century and tightened the screws on their subjects.

Wole Soyinka, The Past Must Address the Present (1986 Nobel Lecture), in 3 OCCASIONAL PAPERS OF THE PHELPS-STOKES FUND, Mar. 1988, at 9.

96. D.I.O. Ewelukwa, The Constitutional Aspects of the Military Take-Over in Nigeria, 2 NIG. L.J. 1, 2 (1967).

97. A.H.M. KirK-Greene, 1 Crisis ANd CONFLict IN Nigeria: A Documentary SOURCE BOOK 1966-1969, at 23 (1971). 
toward anarchy and lawlessness..$^{98}$ Only the army could save the country, and they did on January 15, 1966.

\section{C. $1966-1979$}

In the early hours of January 15,1966 , a group of army officers led by Major Nzeogwu attempted to overthrow the Balewa federal administration. ${ }^{99}$ Though the coup was unsuccessful, they killed some key federal ministers and government functionaries, including the Prime Minister. ${ }^{100}$ The remaining ministers and the Senate President, who was then acting for the President, ${ }^{101}$ invited the General Officer commanding the Nigerian army, General Aguiyi Ironsi, to take over administration of the country. ${ }^{102}$ The army promulgated the Constitution (Suspension and Modification) Decree, which suspended the 1963 Republican constibution ${ }^{103}$ and conferred authority on the federal military government "to make laws for the peace, order, and good government of Nigeria or any part thereof." ${ }^{104}$ General Ironsi, unshackled by the constitution, embarked upon wholesale destruction of the democratic process. ${ }^{105}$ In May 1966, General Ironsi promulgated the Unification Decree, which abolished regional governments. ${ }^{106}$ The Supreme

98. Several reasons have been advanced for the failure of the first republic. See DIAMOND, supra note 12 , at 15 (blaming the failure of democracy on the strains and contradictions in the constitutional structure-which in consolidating regional inequalities and assigning such minuscule powers to so few regions encouraged ethnic political mobilizationmade regional dominance the prerequisite and the basis for intense national political competition and so heightened regional and cultural insecurity); Walter Schwarz, Tribalism and Politics in Nigeria, 22 WORLD TODAY 460 (commenting that democratic order collapsed because historic competing nationalism of Nigeria's three largest tribal nations was never successfully reconciled and united into an overarching Nigerian identity).

99. For a detailed analysis of the failed coup attempt, see ST. JORRE, supra note 19, at 30-47.

100. For a detailed analysis of the 1966 crisis in Nigeria, see generally DIAMOND, supra note 12; William PrafF, The Nigerian State: Political Economy, State, Class and POLITICAL SYSTEM IN THE POST COLONIAL ERA (1988).

101. The President, Dr. Nnamdi Azikiwe, was in Britain for a medical check up.

102. The character of the purported hand-over remains a subject of intense debate. Arguments rage as to whether the events of January 15, 1966, amounted to a revolution or a constitutional change of government. For detailed analysis of both sides of the controversy, see NwABUEZE, supra note 55, at 164-66; Abiola Ojo, The Search for Grundnorm in Nigeria: The Lakami Case, I.C.L.Q. 117 (1971); Ewelukwa, supra note 96, at 1.

103. CONST. (SUSPENSION \& MODIFICATION) DECREE (1966) (Nig.).

104. Id.

105. For an interesting analysis of the structure of military government, see Abiola Ojo, Constitutional Structure and Nature of the Nigerian Government-The New Constitution and Decrees, 10 NIG. L.J. 82 (1976).

106. CONST. (SuSPENSION \& ModifiCATION No. 5) DECREE 34 (1966) (Nig.) provided that "Nigeria shall on the 24th May 1966 . . . cease to be a federation and shall accordingly 
Military Council took all decisions at the center, thus effectively undermining the federal system of government. ${ }^{107}$ Explaining the reasons for the abolition of the federal structure, General Ironsi stated that the Decree "was intended to remove the last vestige of intense regionalism of the recent past, and to produce that cohesion in the government structure which is so necessary in achieving and maintaining the paramount objective of the national military government . . . National unity." 108

General Ironsi never restored equilibrium in Nigeria. The unitary administrative structure never recovered from the January coup attempt. The army gradually disintegrated into splinter groups with loyalties to their ethnic groups. On July 29, 1966, barely six months after assuming office, General Ironsi was killed in a counter-coup led by northern army officers. ${ }^{109}$ After internal negotiations, the coup plotters named Colonel Gowon the Head of State and Commander-in-Chief of the Armed Forces. ${ }^{110}$

The major task for Colonel Gowon was to restore peace in a country severely troubled by ethnic tensions. The Ibos, from the eastern region, felt oppressed by the North and publicly demanded reparation for the carnage unleashed against Ibo military officers and civilians during the July countercoup. ${ }^{11}$ Colonel Ojukwu, then the governor of eastern Nigeria, refused to accept Colonel Gowon's authority, threatening to secede if the North did not make reparations for the brutality unleashed against the Ibos. ${ }^{112}$ Nevertheless, in an attempt to dissipate ethnic tensions, General Gowon, on May 27, 1967, split the four regions into twelve states and appointed eleven military governors and a civilian administrator to run them. ${ }^{113}$ The twelvestate structure split the former eastern region into three states: East Central State, consisting exclusively of Ibos; South Eastern State, comprising mainly of Efiks, Ibibios, Annangs, and Ekois; and Rivers State, inhabited mainly by Ijaws, Ogonis, and Ikweres.

On May 30, 1967, three days after the creation of more states,

as from that day be a Republic by the name The Republic of Nigeria, consisting of the whole territory which immediately before that day was comprised in a federation."

107. For reactions to the unification decree, see ALEX MADIEBO, THE NIGERIAN REVOlution AND THE BIAFran WAR (1980); OluSEgun OBASANJo, My CoMMAND: AN ACCOUNT OF THE NIGERIAN CIVIL WAR, 1967-1970 (1980).

108. Akande, supra note 14, at 15 (Major General Ironsi, broadcast to the nation by the Head of State (May 24, 1966)).

109. See ST. JORRE, supra note 19 , at $65-73$, for an account of the July 29,1966 , coup.

110. General Gowon was not the most senior officer in the army, but he was considered the most likely to Command the loyalty of the soldiers.

111. See ST. JORRE, supra note 19.

112. For the pogrom unleashed against Ibo military officers and civilians following the July 1966 counter-coup, see $i d$. at 65-88.

113. States (Creation \& Transitional Provisions) DeCree 4 (1967) (Nig.). 
Colonel Ojukwu declared the former eastern region the Republic of Biafra. ${ }^{114}$ The federal military government, bent on preserving Nigeria's unity and territorial integrity, embarked upon what General Gowon described as a "short, surgical police action" to crush the rebellion. ${ }^{115}$ The surgical police action resulted in a thirty-month civil war. ${ }^{116}$ On January 12,1970 , in the face of excruciating defeat, Major General Effiong, the Biafran Chief of Army Staff, surrendered to the federal military government. ${ }^{117}$ General Effiong stated: "We are firm, we are loyal Nigerian citizens and accept the authority of the Federal Military Government . . . . We accept the existing administrative and political structure of the federation of Nigeria . . . . The Republic of Biafra hereby ceases to exist." 118 Accepting the surrender, General Gowon described the thirty-month civil war as a "tragic and painful conflict," and stated that the civil war was fought to "[c]rush the rebellion, to maintain the territorial integrity of our nation, to assert the ability of the black man to build a strong progressive and prosperous modern state, and to ensure respect, dignity and equality in the comity of nations for our posterity."119

General Gowon embarked on a reconciliation process and introduced several measures designed to reassure the seceding easterners that the process of reconciliation was genuine. ${ }^{20}$ The Gowon administration reinstated senior civil servants and police officers who served in Biafra and provided money to repair the war-ravaged parts of the region. ${ }^{121}$

Subsequently, in 1974, General Gowon reneged on an earlier promise to hand over power to a democratically elected civilian government by 1976 , stating that Nigeria was not yet ready for democracy. In the 1974 Independence Day broadcast to the nation, General Gowon stated:

It would indeed amount to a betrayal of trust to adhere rigidly to that date .... It was clear that those to lead the nation on the return to civilian rule have not learnt any lesson from past

114. For the full text of the proclamation of the Republic of Biafra and a detailed analysis of the Biafra story, see NWANKWo \& IFEJIKA, supra note 17, at 349-50.

115. FREDRICK FORSYTH, THE BIAFRA STORY 146 (1969).

116. The war started on July 6, 1967. Radio Nigeria Lagos announced on July 7, 1967, that "the Commander-in-Chief of the Armed Forces of Nigeria has issued orders to the Nigerian Army to penetrate the East Central State and capture Ojukwu and his rebel gang." Auberon Waugh \& SuzanNe Cronje, Biafra: Britain's Shame 41 (1969).

117. ST. JORRE, supra note 19 , at $400-01$.

118. TIME, Jan. 16, 1970, at 18.

119. J.I. ElalgwU, GowON: THE BIOGRaPHY OF A SOldier-STATESMAN 136 (1980) (General Gowon, broadcast to the nation (Jan. 15, 1970)).

120. For details of the reconciliation, reconstruction, and rehabilitation programs, see ElAigwU, supra note 119 , at $140-45$.

121. Id. 
experience. Consequently it would be utterly irresponsible to leave the nation in the lurch by a precipitate withdrawal which will certainly throw the nation back into confusion. ${ }^{122}$

On July 29, 1975, a group of senior army officers toppled General Gowon in a bloodless coup. ${ }^{123}$ General Mohammed, a cabinet minister under General Gowon, was named the Head of State. General Mohammed promised to rid the country of corruption and restore democracy by $1979 .{ }^{124}$ As part of its effort to combat corruption, the Mohammed regime established a Corrupt Practices Investigation Bureau and a Public Complaints Commission $^{125}$ to deal with allegations of impropriety against public servants. They constituted panels to investigate the assets of governors and top civil servants. ${ }^{126}$

In September 1975, the Military regime empaneled a fifty-one member Constitution Drafting Committee headed by Chief Rotimi Williams, one of Nigeria's leading lawyers, to draft a new constitution. ${ }^{127}$ The fifty "wise men," as the media reverently called them, represented all states of the federation and were drawn from various segments of society including the legal profession, the universities, and the private sector. ${ }^{128}$ To involve the public in the constitutional drafting process, the Constitution Drafting

122. General Gowon, Broadcast to the Nation (Oct. 1, 1974).

123. ElAIGWU, supra note 119, at 241-50.

124. Id.

125. The Public Complaints Commission had authority to:

Inquire into complaints lodged before it by members of the public concerning any administrative actions taken by any minister or department of the federation or any state government, statutory corporation, local government authorities and other public institutions and of companies whether in the public or private sector and of any officials of any of the aforementioned bodies.

Public COMPlaints COMMISSION ACT, CAP 377 (1990) (Nig.).

126. See FEDERAL GOVERNMENT VIEWS ON THE REPORT OF THE FEDERAL ASSETS INVESTIGATION PANEL (Federal Ministry of Information 1975) (Nig.).

127. Chief Obafemi Awolowo declined to serve on the committee, thus reducing the number to 50. See NigERIAN CONSTITUTION DRAFTING COMMITTEE, 1 REPORT OF THE CONSTITUTION DRAFTING COMMITTEE xiii (Federal Ministry of Information 1976).

128. According to the federal military government:

Members of this committee were selected, first on a basis of two per state, so as to obtain as wide geographical coverage as possible and, secondly from our learned men in disciplines considered to have direct relevance to constitutionmaking, namely... History, Law, Economics and other social sciences especially political science. Eminent Nigerians with some experience in constitution-making were brought in to complete the spectrum. It is enough to ensure that all the broad areas of interest and expertise are brought into the committee, and I am satisfied that members of this committee gathered here today represent a cross section of opinion in this country that can be trusted to do a good job.

Id. (statement of General Mohammed). 
Committee held public hearings in various parts of the country and solicited memoranda and suggestions from members of the public. ${ }^{129}$ On February 13, 1976, just two weeks after creating seven new states, ${ }^{130}$ General Mohammed was assassinated during an unsuccessful coup attempt led by Colonel Dimka. ${ }^{131}$ General Obasanjo, who succeeded General Mohammed, promised to honor the 1979 commitment to hand power back to civilians. On September 14, 1976, the committee, after extensive deliberations and consultations, submitted a draft constitution to the federal military government. ${ }^{132}$ On October 7,1976 , the federal military government turned over the draft constitution to the Constituent Assembly and directed members of the public to send their comments and suggestions to the Constituent Assembly. ${ }^{133}$ The Constituent Assembly was comprised of 203 elected members ${ }^{134}$ and 27 government appointees. ${ }^{135}$ After extensive and sometimes rancorous debate, the Constituent Assembly wrapped up its assignment in August of 1978.

The new constitution introduced a presidential system of government modeled after the American system-a written constitution with an elaborate Bill of Rights, ${ }^{136}$ division of power between the federal government and the states, ${ }^{137}$ a president with executive powers, ${ }^{138}$ federal and state legislatures, ${ }^{139}$ federal and state judiciaries, ${ }^{140}$ and clear separation of powers among the three arms of government. ${ }^{141}$ The constitution also contained elaborate provisions guaranteeing freedoms, rights, and liberties, including freedom of expression and of the press; ${ }^{142}$ freedom of thought, conscience

129. The Constitution Drafting Committee regularly inserted paid advertisements in national and local newspapers requesting memoranda from members of the public.

130. States (Creation \& Transitional Provisions) Decree 12 (1970) (Nig.).

131. ELAIGWU, supra note 119.

132. J.O. OJAKO, 13 YEARS OF MILTTARY RULE IN NIGERIA, 1966-1979, at 178 (1979).

133. The Constituent Assembly was set up pursuant to the Constituent Assembly Act of 1977. See NwABUEZE, supra note 55, at 255 .

134. Members were elected from all the local government areas in the country. FALOLA \& IHONVBERE, THE RISE AND FALl OF Nigeria's SECOND Republic, 1979-1983, at 25, (1985).

135. Government appointees constituted chairmen of subcommittees of the Constitution Drafting Committee and representatives of interest groups that were not adequately represented during the constitution drafting process (such as student organizations and women's groups).

136. CONST. OF $1979 \S \S 30-42$ (Nig.).

137. Id. § 2(2) provided that "Nigeria shall be a Federation consisting of States and a Federal Capital Territory."

138. Id. $\S 5(1)(a)$.

139. Id. $\S 4(1), 84$.

140. Id. $\S 6(1)-(2)$.

141. Id. $\S \S 4-6$.

142. Id. $\$ 36$. 
and religion; ${ }^{143}$ right to life; ${ }^{144}$ right to personal liberty; $;^{145}$ the right to a fair hearing; ${ }^{146}$ right to privacy and family life $;{ }^{147}$ and the right to free assembly. ${ }^{148}$

The enjoyment of these rights, liberties, and freedoms were further secured by vesting the courts with jurisdiction to redress violations. ${ }^{149}$ The government could not interfere with constitutionally guaranteed rights except "in the interest of defence, public safety, public order, public morality, or public health, or for . . . protecting the rights and freedom of other[s]."150

The military government promulgated the draft constitution into law effective October 1, 1979. ${ }^{151}$ Following the promulgation of the constitution into law, the federal military government established the Federal Electoral Commission, which was charged with organizing elections and regulating the activities of political parties. ${ }^{152}$ The military government lifted the ban on party politics on September $21,1978 .^{153}$ Politicians, eager to assume the reigns of power, quickly formed political associations. The Federal Electoral Commission ${ }^{154}$ insisted that political associations seeking registration must reflect the federal character of Nigeria and be open to every citizen of Nigeria despite his or her place of origin, religion, or ethnicity. ${ }^{155}$ After thoroughly screening many applications, the Federal Electoral Commission granted approval to five parties: Great Nigeria People's Party (GNPP); National Party of Nigeria (NPN); Nigeria Peoples Party (NPP); Peoples Redemption Party (PRP); and Unity Party of Nigeria (UPN). ${ }^{156}$

After thirteen years of military dictatorship, conducting elections in a

143. Id. $\$ 35$.

144. Id. $\$ 30$.

145. Id. $\S 32$.

146. Id. $\$ 33$.

147. Id. \$ 34 .

148. Id. $\$ 37$.

149. Id. $\S 42(1)$ provides that "[a]ny person who alleges that any of the provisions of this Chapter [fundamental human rights] has been, is being or likely to be contravened in any State in relation to him may apply to a High Court in that State for redress."

150. Id. $\$ 41$ (1) provides that:

Nothing in sections $34,35,36,37$ and 38 [provisions relating to fundamental human rights] . . . shall invalidate any law that is reasonably justifiable in a democratic society-

(a) in the interest of defence, public safety, public order, public morality or public health; or

(b) for the purpose of protecting the rights and freedom of other persons.

151. CONST. (ENACTMENT) DECREE 25 (1978) (Nig.).

152. CONST. DECREE 73 (1977) (Nig.).

153. FALOLA \& IHONVBERE, supra note 134, at 29.

154. Id. at $28-29$.

155. CONST. OF $1979 \S \S 201-03$ (Nig.).

156. The Federal Electoral Commission chose only these five parties out of more than forty associations that applied for registration. See JOSEPH, supra note 28, at 154 . 
country plagued by ethnic rivalries and a lack of democratic traditions provoked anxieties and fears among various segments of the society. Most Nigerians feared that party elections would ignite ethnic rivalries that had been dormant for thirteen years. Citizens were especially troubled by the domination of the political scene by the same politicians who liquidated the first republic. ${ }^{157}$ The army, to its credit, quickly and positively allayed the fears of the public by showing its willingness to deal ruthlessly with anybody who sabotaged the transition process. ${ }^{158}$ After a ten-month campaign tightly monitored by the military, elections were held for the federal and state elective offices including the Senate, House of Representatives, State Legislature, Governors, and the President. The elections were tolerably free and fair, with no major incidents in any part of the country. ${ }^{159}$ Any disputes that arose from the elections were resolved through the judicial system. ${ }^{160}$ On October 1, 1979, the federal military government, amid pomp and pageantry, handed the reigns of government to the elected civilian administration. ${ }^{161}$

\section{Id. at 160 . The author notes:}

Many of the surviving members of the political class of the First Republic, and their political machines, had moved once again to the fore of the country's politics .... The expectation that history was likely to repeat itself in any elections under a civilian party government was therefore a rational and even self-fulfilling one for the Nigerian citizenry.

158. Extolling the role of the army in the conduct of 1979 elections, Adamu Kurfi writes:

The calm atmosphere prevalent during the 1979 elections was not brought about by the existence of [a] fine political culture in the Nigerian people but was due to the veiled threat of immediate military retribution should law and order break down-and worse, the possibility of postponement of the date of hand-over of power to the civilians.

ADAMU KURFi, THE NigERIAN GENERAL ElECTIONS 1959 AND 1979, at 258 (1982). Similar views were expressed by ADAMU \& OGUNSAwo, Nigeria: The MAKING OF PREsidenTIAL SYSTEM: 1979 GENERAL ElECTIONS. The authors stated that " $t$ ] he presence of a military government which rounded up potential party thugs and effectively checked their activities created a peaceful atmosphere for the elections." Id. at 255-56.

159. For a detailed survey of the 1979 elections, see KURFI, supra note 158; Keith Panter-Brick, Nigeria: The 1979 Election, 14 AfRIKA SPECTRUM 3 (1979); and Richard Joseph, Democratization Under Military Tutelage: Crisis and Consensus in the 1979 Elections, 14 COMP. POL. (1981).

160. Election Petition Tribunals were set up in various states to resolve electoral disputes. See CONST. DECREE 73 (1977) (Nig.). For a detailed analysis of the jurisdiction of election tribunals, see F. OLISA AWOGU, THE JUDICIARY IN THE SECOND REPUBLIC OF NIGERIA, 19791983, at 128-34.

161. General Obasanjo, along with key officers of his administration, retired from the army. 


\section{1979-Present}

The period between 1979 and 1983 witnessed a replay of events and problems that led to the collapse of the first republic. Lack of democratic traditions, corruption, and abuse of power thwarted the nation's ill-prepared experimentation with the presidential system of government. ${ }^{162}$ Religious riots, arson, and political disturbances ruptured prospects for democracy. Nigerian politicians squandered the ideals of presidential democracy. They routinely violated the rule of law ${ }^{163}$ and manipulated the electoral process to retain power. ${ }^{164}$ Economic chaos, corruption, abuse of office, and incessant squabbles among and within the political parties imperilled the nation. ${ }^{165}$

The 1983 general elections exposed the ethnic tensions smoldering beneath the façade of calm held out to the world for four years. Without the army to police the electoral process, politicians flagrantly violated the electoral rules. ${ }^{166}$ President Shehu Shagari was re-elected in a controversial election characterized by electoral malpractice, thuggery, and rigging. ${ }^{167}$ Virtually everyone condemned the election, which was aptly characterized as "a selection carried out through a strong alliance between the police, the Federal Electoral Commission officials, and members of the ruling National Party of Nigeria," with the latter supplying the money. ${ }^{168}$ In December of

162. For a detailed study of the 1982 religious riots and their implications for democracy in Nigeria, see Raymond Hickey, The 1982 Maitasine Uprising in Nigeria: A Note, 83 AFR. AFFAIRS 251 (1984).

163. The most egregious violation occurred in 1980 when the ruling party, the National Party of Nigeria, arrested and deported to Chad a prominent politician from a rival party, the Great Nigeria People's Party, on the unverified and unprovable allegation that he was not a Nigerian. Alhaji Shugaba, the Majority leader of the Great Nigeria People's Party in Borno state, was arrested in the early hours of the morning and transported across the borders by federal agents without an opportunity to defend himself. For details of the deportation and the lawsuit that followed, see Shugaba v. Federal Minister of Internal Affairs, 1 N.C.L.R. 25 (1981).

164. FALOLA \& IHONVBERE, supra note 134, at 227.

165. For a catalogue of abuses and inter-party squabbles, see id. at 78-80; and JOSEPH, supra note 28 , at $164-81$.

166. For details of electoral irregularities, see JOSEPH, supra note 28, at 170-73.

167. The army in taking over from Shagari cited electoral malpractice as one of the reasons for assurning the reigns of power. General Buhari stated:

The people could only look forward to a change in their circumstances by the installation through the mechanism of the ballot box of a government with a more purposeful and responsible leadership . . . . The conduct of the 1983 general election dashed that hope since that election could be anything but free and fair.

FALOLA \& IHONVBERE, supra note 134, at 216 (Major General Buhari, address to the World Press Conference, Lagos (Jan. 5, 1984)).

168. FALOLA \& IHONVBERE, supra note 134 , at 217 . All the politicians engaged in one form of electoral malpractice or the other, but the National Party of Nigeria (NPN) turned out 
1983, the army ousted President Shehu Shagari. The coup plotters named Major General Buhari the Head of State and Commander-in-Chief of the Armed Forces on January 1, 1984. The new military regime suspended the 1979 constitution ${ }^{169}$ and assumed legislative and executive functions at both federal and state levels. ${ }^{170}$ Explaining the reasons for the army take over, General Buhari stated:

Little did the military realize that the political leadership of the second republic would sacrifice most of the checks and balances in the constitution and bring us to the present situation of general insecurity ... . The premium on political power was so exceedingly high that the political contestants regarded victory in election as a matter of life and death . . . . The last general election could be anything but free and fair. There is ample

to be the most guilty of them all. Wole Soyinka, the Nigerian Nobel Prize Laureate, writing about the 1983 election, said:

Discredited, condemned and rejected, even loathed by the majority of Nigerians, the National Party of Nigeria, buoyed by the image-building of its leaders by the western press-meek, unassuming, detribalized, and the guarantor of peace and stability etc. ad nauseam-went confidently ahead to commit the most breath-taking, in sheer scale, electoral fraud of any nation in the whole of West Africa. At every level, from acts of brutal ejection of the opposition at the polling both by "law enforcement agencies" to the simplest but most daring motion of all, swapping the figures at the very point of announcement-the scale of robbery is unprecedented, truly mind-boggling. Wherever all other measures failed, the secretaries to the State Electoral Commissions simply announced the wrong figures or else the Federal Commission in Lagos announced the forgeries.

Wole Soyinka, The 1983 Elections and the Foreign Press, GuARDIAN, Sept. 10, 1983, in FALOLA \& IHONVBERE, supra note 134, at 216-17.

The Academic Staff Union of Universities, the elite national organization of Nigerian university professors, unequivocally condemned the conduct of the 1983 elections:

Whereas the members of the ruling class are wallowing in stinking opulence, the masses of the working people have increasingly been overburdened by economic and social hardships. The people had hoped that the 1983 elections would enable them to replace the corrupt and rich politicians responsible for this state of affairs. But these high expectations have been dashed by the shameful manipulation of the electoral process to reimpose the same notorious people responsible for the hardships. Thus the right of the people to have responsible government and a dignified living has been denied.

Academic Staff Union of Universities (ASUU) National Executive Council Communique, The Election Crisis, Dangers Ahead and the Way Out, in FALOLA \& IHONVBERE, supra note 134, at 222.

169. CONST. (SUSPENSION \& MOdifiCATION) ACT, ch. 64 (1990) (Nig.).

170. Section 2(1) vested in the Federal Military Government power to make laws for the peace, order, and good government of Nigeria or any part thereof with respect to any matter whatsoever. Id. §2(1). 
evidence that rigging and thuggery were related to the resources available to the political parties. This conclusively proves to us that the political parties have not developed confidence in the presidential system of government on which the nation invested much material resources. ${ }^{171}$

General Buhari's depiction of the Shagari administration as corrupt and inept generated public support for the military regime. ${ }^{172}$ Politicians who felt that the National Party of Nigeria massively rigged the 1983 general elections were especially supportive of the military regime.

The military regime quickly embarked upon fighting corruption and revamping the nation's economy. The thrust of the regime's effort was to restore probity in the nation. The Supreme Military Council, the highest organ of the military administration, promulgated several decrees to facilitate the attainment of the regime's objectives. Responding to public anger against corrupt politicians, the military government promulgated a decree specifically targeting corrupt politicians. ${ }^{173}$ Key politicians, including the former president, vice president, governors, and ministers, were detained pending investigation of their assets. The new law empaneled a special military tribunal to try corrupt politicians. ${ }^{174}$ The special military tribunal could dispense with certain evidentiary rules ${ }^{175}$ and procedures of regular courts and had the power to impose harsh sentences ranging from twenty-one years to life imprisonment. ${ }^{176}$ Despite protests from the Nigerian Bar Association, ${ }^{17}$ the tribunal tried and convicted several politicians, including

171. W. AFR., Jan. 7, 1984, at 58. Similarly, General Danjuma, the Chief of Army Staff under General Obasanjo, expressing disgust with the politicians stated:

Democracy had been in jeopardy for the past four years. It died with the elections. The army buried it, they did not kill it. All the parties were involved, but the greatest offender was the National Party of Nigeria (NPN). The NPN had the largest gathering of the worst human beings that Nigeria could produce.

W. AFR., June 30, 1984, at 197.

172. Shehu Ottman, Classes, Crises and Coup: The Demise of Shagari's Regime, 83 AFR. AFFAIRS 441, 456 (1984) (noting that the reaction of the Nigerian public to the coup was decidedly favorable).

173. Recovery of Public Property (Special Military Tribunals) Act, ch. 389 (1990) (Nig.).

174. Id. §5(1)-(2).

175. For a detailed analysis of the modus operandi of military tribunals, see M.A. Owoade, The Military and the Criminal Law in Nigeria, 33 J. AFR. L. 133 (1989).

176. ReCovery of Public Property (SPECIAL Military Tribunals) ACT, ch. 389 , $\S 13(\mathrm{a})-(\mathrm{b})$ (1990) (Nig.).

177. The draconian provisions of the law drew the ire of the Nigerian Bar Association, which directed its members not to appear before the military tribunals. See Jadesola Akande, A Decade of Human Rights in Nigeria, in NEw DIMENSIONS IN NIGERIAN LAW 112 (1989) (noting that the Nigerian Bar Association's objections focused on three main issues: the trials 
governors, ministers, and presidential advisers. ${ }^{178}$

In August of 1985, General Babangida, the then Chief of Army Staff, staged a palace coup and deposed General Buhari. General Babangida, eager to garner public support, openly castigated the Buhari regime for human rights violations. ${ }^{179}$ He promised to respect human rights, to correct the country's social and economic ills, and to lay a solid foundation for democratic rule. ${ }^{180}$ General Babangida expressed the hope that his regime would be the last military administration in Nigeria. ${ }^{181}$ He promised to return power to an elected civilian administration in 1990. The President inaugurated a Political Bureau on January 13, 1986 to find out the wishes of Nigerians as to the preferable political program of governance. ${ }^{122}$ Following the submission of its findings, the Federal Military Government appointed a committee of forty-nine Nigerians to review the 1979 constitution. ${ }^{183}$

The Constitution Review Committee met for six months and submitted a draft constitution to the Federal Military Government. ${ }^{184}$ The draft constitution produced by the committee was ratified by a Constituent Assembly ${ }^{185}$ and subsequently promulgated into law by the federal military

were not conducted in public; the denial of right of appeal from the tribunal's decision; and the composition, nature, and powers of the tribunal).

178. Most of the sentences were later reduced by a Special Appeals Tribunal constituted in 1985 by General Ibrahim Babangida upon assumption of office. All the jailed politicians are now free, enjoying their ill-gotten wealth. Some of the jailed politicians are cabinet ministers serving under the current Abacha's regime.

179. For details of General Babangida's speech, see Babangida Takes Over, W. AFR., Sept. 2, 1985, at 1789.

180. Id.

181. Id.

182. The Political Bureau, headed by Dr. Sam Cookey, had the following terms of reference:

(a) Review Nigeria's political history and identify the basic problems which have led to our failure in the past and suggest ways of resolving and coping with these problems;

(b) Identify a basic philosophy of government which will determine goals and serve as a guide to the activities of government;

(c) Collect relevant information and data for the government as well as identify other political problems that may arise from the debate;

(d) Gather, collate and evaluate the contributions of Nigerians to the search for a viable political future and provide guidelines for the attainment of the consensus objectives;

(e) Deliberate on other political problems as may be referred to it from time to time.

Aniagolu, supra note 65 , at $1040-41$ n.9.

183. See Peter Koehn, Competitive Transition to Civilian Rule: Nigeria's First and Second Experiments, 23 J. MOD. AFR. STUD. 401 (1989).

184. For details of General Babangida's transition program, see Larry Diamond, Nigeria's Search for a New Political Order, 2 J. DEMOCRACY 54 (1991).

185. The Constituent Assembly was established by the CONSTITUENT ASSEMBLY DECREE 
government, ${ }^{186}$ with few amendments. ${ }^{187}$ Besides the introduction of a twoparty system, ${ }^{188}$ the draft constitution paralleled the 1979 constitution. It provided for a presidential system, ${ }^{189}$ federalism, ${ }^{190}$ and separation of powers among the three arms of government. ${ }^{191}$ Additionally, the new constitution contained an elaborate human rights provision. ${ }^{192}$

Another notable feature of the Babangida transition program was that it banned former politicians, particularly those found guilty of corruption and abuse of office, from running for elective offices. ${ }^{193}$ The idea was to create room for "newbreed" politicians untainted by corruption, ethnicity, and all the other social ills that plagued the political process. ${ }^{194}$ To ensure that tainted politicians were screened out of the process, anybody running for office was required to obtain a clearance certificate from the Federal Electoral Commission.

Thereafter, the Federal Military Government lifted the ban on party politics. The National Election Commission (NEC), charged with

OF 1988 and consisted of a Chairman, a Deputy Chairman, 450 elected members, and 111 nominated members.

186. CONST. (Promulgation) ACT 12 (1989) (Nig.). The new constitution was scheduled to take effect on October 1, 1992.

187. The Armed Forces Ruling Council introduced eleven amendments. The first amendment deleted section 15 of the new constitution that declared Nigeria a welfare state, and sections 42 and 43 that provided for free education to age eighteen and free medical care for persons up to age eighteen or older than sixty-five, the handicapped, and the disabled. The second amendment streamlined the jurisdiction of sharia and customary courts of appeal to make them apply at the state level only to matters regarding the personal status of Muslims. Amendment three related to civil service reforms. Amendment four reduced the minimum age requirements for federal and state elective offices from forty to thirty-five for the president, thirty-five to thirty for senators and governors, twenty-five for members of the House of Representatives, and twenty-one for members of state houses of assembly and local government councillors. The fifth amendment replaced the six-year single-term tenure for the president and governors with a four-year, maximum two-term tenure. Amendment six removed from the National Assembly control over matters of national security. The seventh amendment made the federal judicial service commission accountable. The eighth amendment eliminated the provisions establishing an armed forces service commission to supervise compliance with provisions of the federal character principle, i.e. that government bodies such as the military reflect the various elements of the population. Amendment nine reduced the number of special advisers to the president from seven to three. Amendment ten eliminated section 1(4) which outlawed coups and criminalized them. Amendment eleven deleted the provisions which barred the federal government from obtaining external loans without the National Assembly's approval.

188. CONST. OF $1989 \S 220(1)$ (Nig.).

189. Id. \&5.

190. Id. \& 2(1)-(2).

191. Id. $\S \S 4-6$.

192. Id. §§ 32-44.

193. Koehn, supra note 183.

194. Id. 
conducting elections, received a total of thirteen applications for registration. ${ }^{195}$ The National Election Commission recommended six parties for approval but noted that they "were poorly organized with stale ideologies firmly rooted in the past, had little differentiation in their policies and no convincing solutions to current problems." 196 On October 7, 1989, General Babangida announced the rejection of all the political organizations that applied for recognition and stated that the government would form two new parties. ${ }^{197}$ Thus, he set up two new parties: the National Republican Convention (NRC) and the Social Democratic Party (SDP). He requested interested politicians to join the party in their respective local government areas. ${ }^{198}$

The Babangida regime amended the transition program several times and extended the final hand-over date to $1993 .{ }^{199}$ Under the new plan, elections into state offices were to be held in 1991, while the regime postponed the presidential election until June of 1993. State elections were held as scheduled, and the elected civilian governors took office in the states in 1991. This arrangement involved a novel development in Nigerian politics-power sharing between the military and the civilians. ${ }^{200}$ General Babangida retained his position as President and Commander-in-Chief of the Armed Forces while elected civilian governors and state legislators administered the states.

The presidential election proved problematic. After a series of rescheduling, the National Election Commission held the presidential elections on June 12, 1993. Barely twenty-four hours before the elections, a group called the Association for Better Nigeria (ABN) sued, seeking to restrain the National Election Commission from conducting the election. The NEC ignored the lawsuit and went on with the election. The June 12th presidential election differed markedly from previous elections held in the country. Unlike previous elections characterized by electoral malpractice, thuggery, and corruption, Nigeria for the first time in its history conducted what was widely described as a free and fair election. Anxious to derail the transition program, the Association for Better Nigeria sued, seeking this time

195. Id.

196. James Read, Nigeria's New Constitution for 1992: The Third Republic, 35 J. AFR. L. 174,188 (1992).

197. W. AFr., Oct. 16-22, 1989. According to President Babangida, “[a]ll we are saying is that we will not serve our people yesterday's food in glittering new dishes . . . . Many of the associations were either the offshoots of the defunct political parties or surrogates of banned or disqualified politicians."

198. Transition to Civil Rule (Political Parties Registration \& activities) DECREE 27 (1989) (Nig.).

199. Koehn, supra note 183.

200. This is consistent with diarchy proposed by Dr. Azikiwe immediately after the civil war. See NNAmdi AzIKIWE, Democracy wITH MilitaRy VigilanCE (1974). 
to restrain the NEC from announcing the election results. This sparked a plethora of lawsuits in various parts of the country. Various interest groups sued, seeking either to restrain NEC from announcing the results or to compel the NEC to announce the election results. ${ }^{201}$ Amid widespread speculation that Alhaji Abiola, the Social Democratic Party candidate, had won the election, General Babangida annulled the elections and canceled the remaining portion of the transition program. According to General Babangida, his administration canceled the elections "to protect our legal system and the judiciary from being ridiculed and politicized nationally and internationally. "202 General Babangida, surprised and even chastened by the spate of protests, violent demonstrations, and mounting international pressures to restore democracy in Nigeria, stepped down in August of 1993 and appointed an interim government to run the affairs of the nation pending the election of another president. ${ }^{203}$ The interim government led by Chief Shonekan promised to conduct the presidential election in February of 1994. ${ }^{204}$ In December of 1993, General Abacha, the Defense Secretary, toppled the interim government and assumed the position of Head of State and Commander-in-Chief of the Nigerian Armed Forces. ${ }^{205}$

Upon assuming power, General Abacha suspended the constitution, disbanded the existing political structure, and dismissed all elected officials, including senators, members of the House of Representatives, and state governors. ${ }^{206}$ In the face of intense domestic and international pressure to restore democracy in Nigeria, General Abacha reacted to criticism in the traditional military fashion-quelling the populace by brute force. General Abacha has adopted various repressive techniques to suppress public resentment. ${ }^{207}$ The Abacha regime detains citizens without trial and security

201. By one account, at least eight different interest groups filed lawsuits either praying for or against the release of election results. W. AFR., June 28, 1993, at 1078.

202. Id. at 1079. Many suspect that General Babangida was less than candid when he cited electoral malpractice as the main reason for annulling the results of the presidential elections. Strong suspicion persists that personal and ethnic considerations figured prominently in the decision to annul the elections. Chief Abiola, a Yoruba, would have been the second non-Northerner to rule since independence. Moreover, it was rumored that Chief Abiola was planning to probe the military hierarchy, a course of action that would have exposed massive cormuption and human rights violations by the military. See, e.g., Mahmud, supra note 39, at 90 (noting that Babangida did not allow a Yoruba to rule since that was not in the interest of Northern Hausa-Fulani).

203. Peter Lewis, Endgame in Transition? The Politics of a Failed Democratic Transition, 93 AFR. AFFAIRS 323, 328 (1994).

204. Id.

205. Id.

206. Id.

207. For techniques adopted by military regimes to curtail human rights, see Okechukwu Oko, Lawyers in Chains: Restrictions on Human Rights Advocacy Under a Military Regime, 10 HARv. Hum. RTS. J. 257 (1997). 
agents selectively harass lawyers for human rights activities. ${ }^{208}$

General Abacha has promised to hand over power to a democratically elected civilian administration in $1998 .{ }^{209}$ Pursuant to this, he impaneled a Constitution Conference Committee to draft a new constitution for Nigeria. The committee has since proposed a new constitution for the country. However noble General Abacha's intent may be in establishing a durable democracy in Nigeria, the truth is that Nigerians are becoming increasingly cynical about the workability of a western-style democracy in Nigeria. ${ }^{210}$ Thirty-five years of gyration from the Westminster model to military rule and to the more recent presidential system has left citizens dismayed and disillusioned. In a 1994 address, General Abacha succinctly captured the mood of the nation:

After nearly three and a half decades of hopes raised and hopes dashed, it should not be very surprising that Nigerians are weary and worried. Having gone through several years in which their faith in the national enterprise has been abused and affronted, our people's impatience with government and almost total distrust of its functionaries can no longer be dismissed as merely cynical. ${ }^{211}$

As Nigeria tinkers with the political order, an examination of the impact of ethnicity on the political process will help to understand and devise a workable constitutional framework that will preserve peace in the country.

208. Despite incessant harassment and brutality, Nigerian human rights organizations have been remarkably resilient in demanding the restoration of democracy.

209. General Abacha, in the 1995 Independence Day broadcast to the nation, stated:

To establish the foundation of a durable democracy, we estimate that the time required will cover a period of no more than thirty-six months. A detailed and carefully considered program of sequence of events that will lead to that deadline has been worked out. This sequence will begin with a stage by stage phased handing over at the local government level. It has been calculated that the completion date, at the level of the presidency when the final tier of a democratically elected civil government shall be installed, should be feasible for October 1, 1998.

W. AFR., Oct. 9, 1995, at 1557 (General Abacha, 1995 Independence Day Broadcast).

210. Nigerians are deeply suspicious of General Abacha's transition program that Chris McGreal aptly characterized as "a legacy of his predecessor's breach of faith." Chris McGreal, A nation stained by Abacha's rule, GUARDIAN, Nov. 18, 1995, available in 1995 WL 9953200.

211. General Abacha, Address to the Nation on the Presentation of the 1994 Budget in Abuja (Jan. 10, 1994), available in LEXIS AL/WO 316/WA 1994. 


\title{
III. ETHNicity AND THE NIGERIAN POLITICAL PROCESS
}

Ethnicity manifests itself predominantly in the political process. ${ }^{212}$ The political process attempting to establish western-style constitutional democracy has become increasingly polarized, divisive, and counterproductive. ${ }^{213}$ Despite integrationist rhetoric, political elites have not been successful in forming a truly national party. Ethnic-based politics ultimately undermines social equilibrium and national unity that should be the political process' chief goals. Walle Engedayehu, an Ethiopian scholar, eloquently describes the impact of ethnic-based politics on the democratic process:

\begin{abstract}
Ethnic-based politics has the propensity of intensifying group conflict since the primary interests of political actors in such a setting do not work for the collective good of the nation. Ethnic parochialism in politics does not only limit the broader examination of issues affecting the nation, but also encourages separatism in the social and political life of that nation. Both can be counterproductive to peace, stability and democracy. ${ }^{214}$
\end{abstract}

This portion of the paper reviews the impact of ethnicity on the formation and organization of political parties in Nigeria since the country attained independence in 1960 .

\section{A. The Ethnicity and Party Politics}

One aspect of the political process that has repeatedly succumbed to ethnicity is the organization of political parties. ${ }^{215}$ Formation of political

212. Ike Udogu, The Allurement of Ethnonationalism in Nigerian Politics: The Contemporary Debate, 29 J. ASIAN \& AFR. STUD. 159-71 (1994) (generally noting that the potency of ethnicity remains salient in Nigerian politics); Pita Agbese, Ethnic Conflicts and Hometown Associations: An Analysis of the Experience of the Agila Development Association, 43 AFR. TODAY 139 (1996) (noting that in Africa political issues are perceived in ethnic terms and political competition is structured primarily on an ethnic basis).

213. DemoCracy AND PluRAlism In AFrICA 195 (Dov Roven ed., 1986) (commenting that efforts to institutionalize democracy (i.e. political parties, elections, electoral competition for office, etc.) have awakened, strengthened, and even created ethnic or ethno-national identities, and thus have, in reality, countered the efforts of centralized power to integrate, unify, institutionalize, and define the nation).

214. Walle Engedayehu, Ethiopia: Democracy and The Politics of Ethnicity, 40 AFr. TODAY 29, 50 (1993).

215. General Mohammed, whose regime set the stage for the second republic from 1979 83, was so concerned about the negative impact of party politics that he advised the Constitution Drafting Committee that "[i]f during the course of your deliberations, and having regard to our disillusion with party politics in the past, you should discover some means by which government can be formed without the involvement of political parties you should feel 
parties along ethnic, rather than ideological lines, may be a consequence of politics in plural societies, especially in developing sectors of the world. ${ }^{216}$ Political parties conjure different images in the minds of Nigerians. For some, they represent the state itself; for others, a political party is a forum for citizens from the same ethnic group to protect their interests. The underlying assumption in both views is that a political party consists of persons from the same ethnic groups who share an identifiable interest in gaining control of the state. Despite increased sophistication and political development, most Nigerians have been unable to separate political parties from the state. This attitude encourages citizens to join parties controlled or dominated by politicians from their ethnic group, thereby preventing the emergence of truly national parties-a sine qua non for durable democratic order. ${ }^{217}$

Ethnicity has always been the banner under which party loyalty is generated. ${ }^{218}$ While class may be the initial unifying factor in the composition of political parties, ethnic groups quickly realigned their support and closed ranks to maintain hegemony over the process or to stave off perceived threats. For example, during the second republic, many perceived the National Party of Nigeria (NPN) as an assemblage of millionaires united more by class than ethnicity. ${ }^{219}$ The hopes that ideology had finally taken precedence over ethnicity and that the political process had rid itself of ethnicity were quickly dashed as several party members broke ranks with the NPN and openly aligned with their ethnic groups. Even President Shehu Shagari, the leader of NPN, crudely appealed to religious and ethnic sentiments by publicly stating that voting for Christians was wrong for

free to recommend [them]." NIGERIAN CONSTITUTION DRAFTING COMMITTEE, 1 REPORT OF THE CONSTITUTION DRAFTING COMMITTEE xiii (Federal Ministry of Information 1976).

216. Alvin Rabushika \& Kenneth A. Shepsle, Politics in Plural Socteties: A THEORY OF DEMOCRATIC INSTABILITY 20-21 (1972).

217. S.M. Lipset notes:

A stable democracy requires a situation in which the major political parties include supporters from many segments of the population. A system in which the support of different parties corresponds too closely to basic social divisions cannot continue to operate on a democratic basis, for it reflects a state of conflict so intense and clear cut as to rule out compromise.

JOSEPH, supra note 28, at 25.

218. Chudi Uwazurike, Confronting Potential Breakdown: The Nigerian Redemocratisation Process in Critical Perspective, 28 J. MOD. AFR. STUD. 55, 76 (1990) (noting that in Nigeria, first ethnicity, then class, and lately religion have provided the basis for political mobilization with varying degrees of success; thus far, regional geo-ethnicity still remains the most potent).

219. Ottman, supra note 172, at 444 (noting that the ranks of NPN were filled by a staggering blend of what one party ideologue called "men of fibre and integrity . . . timber and caliber") (quoting ChUba OKadigBo, The Mission of the NATIONAL PARTY OF NigERIA 38-39 (1980)). 
Muslims. 220

Ethnicity remains the driving force behind the formation of political parties in Nigeria for three main reasons. ${ }^{21}$ First, the peculiar political and economic conditions in Nigeria have contributed immensely to the prevalence of ethnicity. Nigeria operates a semi-socialistic economy in which the government largely determines what private businesses can and cannot do. Before 1992, government involved itself in all kinds of businesses ranging from hotel management to the trucking industry. ${ }^{222}$ This provided a broad range of options for politicians to enrich themselves and service their political supporters (or clients). "Each ethnic group seeks to be the dominant player in the political process and thus control and redirect social and economic amenities to their ethnic group. ${ }^{223}$ The perception of the state as the distributor of largesse encourages citizens to coalesce around their ethnic leaders. Many Nigerians conceive state power as "a congeries of offices which can be competed for, appropriated and then administered for the benefit of individual occupants and their support groups."224 Some people believe that the only way they can get ahead in modern pluralistic Nigerian society is to elect politicians from their clan. These beliefs are more prevalent among the illiterate members of the society. In the largely unsophisticated communities where citizens lack the capacity to evaluate party programs objectively, failing to support a party that enjoys popular support in the community was close to an abomination. ${ }^{225}$ Even among the sophisticated citizenry, ethnicity remains a major force in politics. Typically, a Nigerian embraces the belief that "the real hope of socioeconomic betterment lies in the success of his relative, or other son of

220. Soyinka, supra note 168, at 129 (noting that President Shagari's anti-tribalism was no doubt proven when he campaigned in his home state, Sokoto, and appealed so crudely to both religious and tribal sentiments).

221. Richard Sklar questions traditional assumptions about the role of ethnicity in party politics and maintains that class, rather than ethnicity, is the driving force behind formation of political parties. He writes that "tribalism was a mask for class privilege and that parties were really instruments used to promote class interests in the acquisition and retention of regional power." Richard Sklar, Political Science and National Integration-A Radical Approach, 5 J. MOD. AFR. STUD. 6 (1967).

222. For a detailed analysis of privatization in Nigeria, see Okechukwu Oko, Government Control of Public Corporations and Parastatals (unpublished LL.M. dissertation) (on file with author).

223. Jeffrey Herbst, Is Nigeria a Viable State?, 19 WASH. Q. 151, 156 (1996) (noting that the inability of ethnic groups to subordinate selfish interests to the overriding interest of the nation results in a pernicious political dynamic in which control of the state became critical in order to regulate the flow of patronage).

224. JOSEPH, supra note 28 , at 63.

225. K.W.J. Post, The Nigerian Federal Election of 1959, at 396 (1963) (commenting that "for a man to support a political party different from the one supported by the rest of the community amounted almost to a repudiation of his own people"). 
the soil, in getting a lien on the public purse and trickling a few coins down to him." 226 This perception proves well-founded given that ethnic groups with the most politicians in government enjoy more modern facilities than their minority counterparts. ${ }^{27}$

The second reason results from the fact that far too often politicians frame political issues in Nigeria as preserving values dear to one ethnic group. .28 $^{2}$ For example, any issue that poses a threat to Islam, however veiled, generates opposition from all Moslems. Similarly, politicians from the South easily garner support by accusing Moslems of attempting to dominate other religious groups. In the first republic, 1960-66, the political parties used unfounded ethnic accusations to generate support. The Hausacontrolled Nigeria Peoples Congress (NPC) spread rumors that the Action Group (AG), a Yoruba party, would ban Islam. The AG accused the NPC of attempting to force Islam upon the South. The National Council of Nigerian Citizens (NCNC), an Ibo-controlled party, was accused by both parties of scheming to stack the federal bureaucracy with Ibos. Such vile rhetoric and mischievous appeal to the peoples' fears generated considerable support for the parties. ${ }^{229}$ Political cleavages along religious lines manifested themselves again in the second republic, 1979-83. The Sharia debate in 1979 illustrated the phenomenon. The Muslim members of the Constituent Assembly had suggested the insertion of a special provision in the 1979 Constitution to establish a Sharia Court of Appeal to hear appeals on matters of Islamic personal law. Upon rejection of this suggestion, all Muslim members of the Constituent Assembly stormed out of the meeting and boycotted further deliberations of the assembly. It took the intervention of the Head of State to bring them back.

Thirdly, ethnicity serves as a potent tool for manipulating the electoral process. ${ }^{230}$ Nigerian politicians often mobilize the masses not toward the attainment of goals beneficial to the entire nation, but to secure narrow,

226. Richard A. Joseph, Political Parties AND Ideology In Nigeria 90 (1987).

227. For a classic study of deprivations suffered by Ogoni minorities in Nigeria, see Eghosa Osaghae, The Ogoni Uprising: Oil Politics, Minority Agitation and the Future of the Nigerian State, 94 AFR. AFFAIRS 325 (1995).

228. Mafeje Archie, The Ideology of Tribalism, 9 J. Mod. AFR. STuD. 253, 259 (noting that by whipping up communal fears and suspicions, by casting each election as a threat to the sacred values and even the survival of the ethnic community, and by establishing tribalism as the ideology of politics, the politicians and business allies of each regional party were able to entrench themselves in power).

229. DIAMOND, supra note 12, at 43.

230. Modernization and the Politics of Communalism: A Theoretical Perspective, in Nigeria: MODERNIZATION AND THE POLITICS OF COMMUNALISM 19 (Melson \& Wolpe eds., 1971), states that "mass participation in the political process encourages aspiring politicians to make appeals to the most easily mobilized communal loyalties and to define themselves primarily as the representatives of community interests." 
parochial sectional interests. ${ }^{231}$ Nigerian politicians have historically appealed to ethnic loyalties and will continue to do so, especially when such a strategy yields clearly demonstrable results. ${ }^{232}$ In politics, ethnicity has a very high survival value. ${ }^{233}$ For the contestants, it ensures victory at the polls. ${ }^{234}$ For the masses, ethnic identification helps them live richly and powerfully. Dudley, an authority on Nigerian politics, succinctly captures the manipulation of ethnicity by Nigerian political elites: "What has been called 'tribalism' is seen to be part of the mechanism through which the political elite maintains itself in power and exercises its influence. It is therefore an attribute of elite behavior . . . the educated became the chief proponents and purveyors of parochialism and particularistic values.

For any, or a combination of all three reasons, political parties usually revolve around ethnic lines. In the first republic, political parties were regionally-based, with loyalties to their ethnic groups. ${ }^{236}$ For example, the NCNC was seen as an Ibo party, the AG was supported by the Yorubas in the western part of the country, and the NPC drew its support from the North. ${ }^{237}$ Each party made no pretense about its tribal base and made no

231. Politicians frequently remind their followers of the serious consequences that will result should politicians from rival ethnic groups attain power. They typically promise their ethnic followers that if elected into office, they will protect and advance their ethnic interests. Anthony Smith characterizes this phenomenon as "internal colonialism" and concludes that "the implication is that autonomous ethnic control over the homeland's resources and budget would restructure the economy to support the interest of, and preserve intact, the community which would otherwise suffer further decline and assimilation or deprivation." ANTHONY SMITH, THE ETHNIC ORIGIN OF NATIONS 163 (1986).

232. DIAMOND, supra note 12 , at 41 (notes that in a multi-ethnic society that was modernizing but still largely illiterate, where expectations were growing faster than resources, no electoral strategy seemed more assured of success than the manipulation of ethnic pride and prejudice).

233. JOSEPH ROTHSCHILD, ETHNOPOLITICS: A CONCEPTUAL FRAMEWORK 173 (1981) (arguing that the most emotionally intense type of political solidarity is currently in ethnic rather than in class or formal ideological affinities).

234. Wilson, supra note 5, at 446 (noting that ethnic groups are especially convenient bases for generating mass political support because they provide the loyalty not merely of ideologues but of family members).

235. B.J. Dudley, INSTABILITY AND Political ORDER: Politics and Crisis in Nigeria 44, 51 (1973). The late Professor Kenneth Dike, Africa's leading historian and former Vice Chancellor of the University of Ibadan, stated: " $[1] \mathrm{t}$ must be said to our shame that the Nigerian intellectual, far from being an influence for national integration, is the greatest exploiter of parochial and clannish sentiment." VAN DEN BERGHE, POWER AND PRIVILEGE IN AN AFRICAN UNIVERSITY 224.

236. For an interesting discussion of the emergence of political parties in Nigeria, see Minton F. Goldman, Political Change in a Multi-National Setting, in DYNAMIes OF THE THIRD World: Polmtical AND Social Change (David Schmitt ed., 1974).

237. Post, supra note 225 , at 13 (noting that from 1951 onwards, generally almost all Ibos supported the NCNC, while most Yorubas backed Action Group, and all but a small minority of the Hausa and Fulani were associated, if indirectly, with the NPC). 
attempt to broaden its power base to include other ethnic groups. Framing electoral issues in ethnic terms and manipulation of ethnic sentiments by politicians generated conflicts and tensions that ultimately resulted in the collapse of the first republic. 238

The political parties that emerged in the second republic, 1979-83, were constitutionally enjoined to uphold the idea of a united Nigeria and to embrace the constitutional ideal of federal character. ${ }^{239}$ Consequently, they were less regional than the old parties, but political affiliations still ran along ethnic lines. ${ }^{240}$ Each party tended to be identified with the ethnicity of its leaders. For example, the Nigeria Peoples Party was viewed as the "Ibo" party because of Dr. Nnamdi Azikiwe; the Unity Party of Nigeria was seen as the "Yoruba" party because of Chief Awolowo; the Peoples Redemption Party was identified as a "Hausa" party because of Mallam Aminu Kano. The National Party of Nigeria was much more broad-based than the others; nevertheless, strong suspicions persisted that it was a party for the Hausas, apparently because the presidential candidate, Alhaji Shehu Shagari, was Hausa. ${ }^{241}$

The two-party system introduced by the Babangida administration during the ill-fated third republic, between 1990 and 1993, considerably reduced the impact of ethnicity upon party membership. More by default than by reasoned calculation, the formation of two political parties by executive fiat broke the ethnic lines that historically determined party membership in Nigeria. Politicians, unable to set their own ideology or forge coalitions, were forced to join either of the two parties. Speculations were that ethnicity had finally crumbled under the pressures of democracy. We may never know the truth because the army aborted the democratic process before any scientific finding could be made on the impact of a twoparty system on ethnicity. ${ }^{242}$ The fourth republic, promised by General

238. Horowitz eloquently describes the deleterious effects of vile ethnic rhetoric on the society:

By appealing to electorates in ethnic terms, by making ethnic demands on government, and by bolstering the influence of ethnically chauvinistic elements within each group, parties that begin by merely mirroring ethnic divisions help to deepen and extend them. Hence the oft-heard remark in such states that politicians have created ethnic conflict.

HOROWITZ, supra note 15 , at 291.

239. CoNST. OF $1979 \S 14(3)$ (Nig.).

240. See Olatunde Ojo, The Impact of Personality and Ethnicity on the Nigerian Elections of 1979, 28 AFR. TODAY 47 (1981).

241. Id. (noting that major ethnic groups voted overwhelmingly for candidates of their own ethnic origin).

242. For an operational assessment of the impact of a two-party system on the Nigerian political process, see Oyedele Oyediran \& Adigun Agbaje, Two-Partyism and Democratic Transition in Nigeria, 29 J. MOD. AFR. STUD. 213 (1991). 
Abacha to begin in 1998, reverted to a multi-party system and approved five political parties on September 30, 1996. ${ }^{243}$ The fourth republic will confirm whether class and ideology have finally emerged over ethnicity as the ultimate determinants of party membership. ${ }^{244}$

\section{RESPONDING TO THE PROBLEMS OF ETHNICITY IN NIGERIA}

The prospect of a durable social order depends mightily on Nigeria's ability to construct a mechanism that can fairly address the ethnic problems that frustrated past attempts to set up democracy. Modern political apparatus, especially the breakdown of the two major divisions (North and South) into several states, failed to dissipate ethnic sentiments and loyalties among the ethnic groups. ${ }^{245}$ Each ethnic group retains its identity and seeks to dominate the others. Ethnicity becomes heightened by modernization, especially migration from rural areas to the city. As citizens move from rural to urban areas in search of progress, they carry with them certain attitudes and biases that prevent complete integration with people from other ethnic groups. The urban city dweller becomes "concerned lest his ethnic group falls behind others in the struggle for wealth, power, and status. "246 Sometimes administrative rules and practices prevented interaction with other ethnic groups. ${ }^{247}$ Mutual distrust among the various ethnic groups in Nigeria is well-documented. ${ }^{248}$

African political elites have adopted several legal and political

243. Nigeria: Review, AFR. REv. WORLD INFO., Feb. 1, 1997, available in 1997 WL 10204078.

244. For General Abacha's transition program, see SoYINKA, supra note 37, at 159-61.

245. OSITA EZE, HUMAN RIGHTS IN AFRICA 135 (1984), stated:

With independence . . . ethnic conflicts have surfaced and have in many African countries threatened the fragile geo-political bases of the new states. It was thought that the process of modernization would lead to the accommodation of the various primordial loyaities; the history of many African states tends to point to the contrary.

246. Young, The Politics of Cultural PluRalism 464.

247. OKWUDIBA, supra note 29 , at 115 (noting that the Southerners who migrated to the North were forced to live in segregated housing and to educate their children in separate schools, and were prevented from acquiring freehold title to land); DIAMOND, supra note 12 , at 26 (noting that Northern Muslims were forbidden on both religious and administrative grounds to associate with Southerners whom they were taught to regard as "pagans and infidels").

248. VAN DEN BERGHE, supra note 235 , at 252 , summarized the typical position thus:

By and large, people expect members of ethnic groups other than their own to be "tribalists," i.e., to be biased in favor of their fellow ethnics and against "strangers". . . . Most people assume that all others except those in the same circle of intimates (fellow Kinsmen, townsmen, or persons linked by patronclient ties) will behave in ways which further the person's interest at the expense of oneself. 
measures to combat the deleterious effects of ethnicity. ${ }^{249}$ These techniques include: constitutional democracy with an emphasis on representative government; a federal system of government ${ }^{250}$ with considerable autonomy for the state and local governments; a one-party state ${ }^{251}$ with constitutional rules that enjoin governments to ensure fair representation of ethnic groups in government; ${ }^{252}$ and recently shared key elective positions among ethnic groups. ${ }^{253}$ African governments try to smother ethnic rivalries through economic programs and political patronage ${ }^{254}$ targeted at minority ethnic

249. The devastation wreaked on countries by ethnic rivalries was succinctly depicted by Donald Horowitz. He states:

The importance of ethnic conflict, as a force shaping human affairs, as a phenomenon to be understood, as a threat to be controlled, can no longer be denied. By one reckoning, ethnic violence since World War II has claimed more than ten million lives, and in the last two decades ethnic conflict has become especially widespread. Ethnicity is at the center of politics in country after country, a potent source of challenges to the cohesion of states and international tension . . . . Ethnicity has fought and bled and burned its way into public and scholarly consciousness.

HOROWITZ, supra note 15, at 238.

250. Benjamin Neuberger, Federalism in Africa: Experience and Prospects, in FEDERALISM AND POLITICAL INTEGRATION 171, 173 (1984) (noting that federalism had an appeal in the late 1950 s and early 1960 s as a middle of the road approach between the poles of unitary centralism and outright secession. Intra-state federalism was seen as the only way to accommodate tribal and linguistic diversity within one political system. Federalism within the state was the outcome of devolution and thus its function was more to mediate between the ethnic groups than to integrate them into one uniform whole.) (footnotes omitted).

251. Some African nations, upon attaining independence, established a one-party state as a means of offsetting the divisive effects of multi-partisanship. Anyang' Nyong'o brilliantly articulates the arguments for the establishment of a one-party state:

The single party would promote national unity; the peoples' efforts would be directed towards nation building and not wasted on politics; since people generally agreed that the government was to engage itself in development, party politics was not necessary; whatever differences would emerge, these could be freely discussed under the single-party regime as democracy and human rights would be practiced.

Peter Anyang' Nyong'o, The One Party State and its Apologists, in 30 Years of INDEPENDENCE IN AFrICA: THE LOST DECADES? 3 (Peter Anyang' Nyong'o ed., 1992). The one-party system turned out to be a colossal failure in Africa as tyrants and despots used the machinery of state to oppress and silence dissidents. As Anyang' Nyong'o observed:

No one party regime in Africa can boast of democratic practice or a good record on human rights. Sekou Toure's Guinea had its own Gulag Archipelagos; Mobutu' Zaire excelled in repression as a policy of maintaining a kleptocratic regime in power; Banda' Malawi has been the best run police state in Africa.

Id.

252. See infra text accompanying notes 258-63.

253. See infra text accompanying notes 333-40.

254. Attempts at promoting national unity have included economic policies, political patronage, and mass education. See Anthony Smith, The Nation: Invented, Imagined, 
groups. ${ }^{255}$ Both strategies, legal and political, failed chiefly because their efficacies require a level of good faith from politicians and technocrats which they are either unable or unwilling to display. ${ }^{256}$ Most political elites continue to harbor deep-seated ethnic loyalties that diminish their capacity to make the necessary concessions and compromises required by the democratic process. ${ }^{27}$ This portion of the paper will examine three available options for dealing with the resurgence of ethnicity. The options include: introducing legal rules to address minority concerns; attacking the social forces that engender ethnic rivalries; and partitioning the country.

\section{A. Promoting National Unity Through Legal Rules}

Before 1979, efforts at national integration were largely uncoordinated, unorganized, and solely dependent on the good faith of politicians and technocrats. Entrusting an issue as vital as integration to politicians with an uncontrollable propensity for self-aggrandizement proved calamitous. Without legal rules and democratic traditions to discipline their selfish tendencies, politicians behaved opportunistically, doing whatever was necessary to secure votes. Acutely aware of the citizens' commitment to their ethnic groups ${ }^{258}$ and eager to promote unity in Nigeria, 259 the

Reconstructed?, 20 MillenNIUM 353, 364 (1991).

255. For example, a Commission of Inquiry - set up by the British Colonial government in Nigeria to investigate allegations of discrimination and unfair treatment by minorities in Nigeria-recognized as valid the fear of oppression and discrimination widely held by minorities in Nigeria and recommended certain safeguards for allaying the fears of minorities. These recommendations included the centralization of the police force, a constitutional guarantee of rights, decentralization of functions to provincial authorities, and the establishment of a development board to advise on the physical development of Niger Delta areas and midwestern Nigeria. See Report CMND 505 (1958), in NwABUEZE, supra note 55. at 151 .

256. Professor B.O. Nwabueze, one of Africa's leading constitutional law scholars, describes why federalism has been unable to resolve ethnic conflicts in Africa:

For federalism to be able to resist failure, the leaders and their followers must "feel federal". . . they must be moved to think of themselves as one people with one common self-interest capable where necessary of overriding most other considerations of small group interest. It is not enough that the units of a federation have the same ideal of "good" but that the good for anyone must be consciously subordinate to or compatible with the good of all.

Akande, supra note 14 , at 28.

257. In his popular critique of group theory, Mancur Olson notes that "if the individuals in any large group are interested in their own welfare, they will not voluntarily make sacrifices to help their group attain its political (public or collective) objectives." MANCUR OLSON, THE LOGIC OF COLLECTIVE ACTION 126 (1971).

258. The CDC observed that "as a general rule, every Nigerian owes or is expected to owe some loyalty to his community or sub-community." NIGERIAN CONSTITUTION DRAFTING COMMITTEE, 1 REPORT OF THE CONSTITUTION DRAFTING COMMITTEE xiii (Federal Ministry 
Constitution Drafting Committee (CDC), in 1979, sought to promote national loyalty through legal rules. Specifically, the CDC included two main legal rules designed to promote national unity. The first provision demanded that a candidate, to be elected, must have the support of a broad segment of the country. The second provision called for a fair representation of all the existing ethnic groups in government. Both provisions were subsequently ratified by the Constituent Assembly and incorporated into the constitution.

To ensure that the president enjoyed national support, the 1979 Constitution of the Federal Republic of Nigeria provided that besides securing a majority of the votes cast at the election, a president must secure not less than one-quarter of the votes cast at the election in each of at least two-thirds of all states in the federation. ${ }^{260}$ This provision was designed to elect a president acceptable to a broad segment of the country. An executive president, unlike a ceremonial president, needs acceptability among various ethnic groups to be able to act decisively.

The second constitutional provision enjoined all levels of government to ensure a fair representation of all ethnic groups. Section 14(3) provided:

The composition of the Government of the Federation or any of its agencies and the conduct of its affairs shall be carried out in such manner as to reflect the federal character of Nigeria and the need to promote national unity, and also to Command national loyalty thereby ensuring that there shall be no predominance of persons from a few States or from a few ethnic or other sectional groups in that government or in any of its agencies.

Similarly, state and local governments were required to "recognize the diversity of the peoples within its area of authority and the need to promote a sense of belonging and loyalty among all the peoples of the Federation." 261 This novel and extensive constitutional provision followed the recommendation of the CDC, which noted: "Once it is agreed or provided that the component states and all ethnic groups shall be accorded fair and equitable treatment, it follows logically that no few states or combination of a few ethnic groups shall be permitted to dominate the government to the exclusion of others. ${ }^{262}$

of Information 1976).

259. The CDC noted that loyalty to one's community ought not to be allowed to inhibit or detract from national unity and resolved that "[t]he state shall foster a feeling of belonging and of involvement among various sections of the country, to the end that loyalty to the nation shall override sectional loyalties." Id.

260. See CONST. OF $1979 \S \S 123,125,126(1 \mathrm{a}), 126(2 \mathrm{a})$ (Nig.).

261. Id. § 14(2).

262. NigERIAN CONSTITUTION DRAFTING COMMTTEE, 1 REPORT OF THE CONSTITUTION DRAFTING COMMITTEE viii-ix (Federal Ministry of Information 1976). 
Explaining the reason for this novel constitutional provision, the CDC observed:

There had in the past been inter-ethnic rivalry to secure the domination of government by one ethnic group or combination of ethnic groups to the exclusion of others. It is therefore essential to have some provisions to ensure that the predominance of persons from a few states or from a few ethnic or other sectional groups is avoided in the composition of government or the appointment or elections of persons to high offices in the state. ${ }^{263}$

"Federal character," as the media called it, was meant to have implications far broader than increasing social representation of different ethnic groups in government. It denounced domination of government by one ethnic group and sought to give all ethnic groups a sense of belonging. The CDC believed that including such an extensive policy statement in the constitution would allay the fears of exclusion widely nursed by some ethnic groups, and hopefully generate loyalty to the nation.

The CDC encouraged Nigerians to think that ethnic problems could be eliminated or at least contained by legal rules. Nigerians realized quickly that the efficacy of legal rules depended on social and political realities in the country. The prognosis for integration suggested by the Constitution Drafting Committee and included in the constitution was severely weakened by politicians and technocrats who abused it for selfish ends. The lofty constitutional ideal became embroiled in politics as politicians and key government functionaries openly and aggressively identified with their respective ethnic groups and pushed for preferential treatment for their people.

Moreover, the above provisions in some respects severely constrained efforts to promote unity. By constitutionally mandating "federal character," the system confessed its inability to promote unity and unwittingly rendered simmering ethnic tensions more intractable and less amenable to solution. In the hope of achieving increased social representation of all ethnic groups, the Nigerian government traded a long-term search for integration for shortterm equilibrium. Government was forced to maintain a delicate balance between merit and allaying the ethnic minority's fear of ethnic domination or exclusion. The balancing act proved particularly invidious as government functionaries readily sacrificed merit at the altars of ethnicity. ${ }^{264}$ Too much

263. $I d$.

264. Alhaji Ali Ciroma, the President of the Nigerian Labor Congress, stated: "Any government that believes in federal character is basing its options on a wrong premise. This is because if you want to apply federal character as a yardstick for giving people opportunities, 
emphasis on ethnicity unnecessarily injected ethnic sentiments in all matters of national concern, thus fracturing loyalty to the nation. ${ }^{265}$ According to Dr. Okere: "If ethnic and state considerations have to be the salient factors in determining public appointments, would hankering after power and high federal offices not lead to inordinate and aggressive identification with the ethnic group or the state to the detriment of higher loyalty to the Nigerian nation?"266

Ethnic loyalties may decrease if Nigerian politics becomes less of a zero-sum game in which the winners partake of the national cake while the losers wallow in abject poverty and misery. ${ }^{267}$ The sense of loss and even alienation felt by those who describe themselves as minorities engender pressure to question every facet of the civil society. ${ }^{268}$ Many complain about the revenue allocation formula, the distribution of government appointive positions, and even the legitimacy of the government. Though some of these sentiments are misguided, they all cannot be dismissed as totally unwarranted. Minority ethnic groups have watched helplessly as the northern ethnic groups enjoy and squander the nation's resources. Northern ethnic groups have repeatedly exhibited a tendency to behave opportunistically, needlessly exploiting and dominating other groups. The feeling of exclusion and subjugation among the Ibos in 1966 resulted in the secessionist bid that resulted in a thirty-month civil war. Additionally, the feeling that the North was trying to manipulate the West into submission led to the 1966 western regional crisis.

Citizens profess commitment to ethnicity because it is efficient. ${ }^{269}$ It serves the major purpose of assuring success and enjoyment of the facilities

you will be denying other qualified Nigerians opportunities. " N.Y. TnMES, July 20, 1986, at 15.

265. For a critical analysis of "federal character," see A.A.M. Kirk-Greene, Ethnic Engineering and the "Federal Character" of Nigeria: Boon of Contentment or Bone of Contention?, 6 ETHNIC \& RAClaL STUD. 457 (1983).

266. B.O. Okere, Fundamental Objectives and Directive Principles of State Policy Under the Nigerian Constitution, 3 NIG. JURID. REV. 74, 75-76 (1988).

267. LEWIS, POLITICS IN WEST AFRICA 76 (arguing that plural societies cannot function peaceably if politics is regarded as a zero-sum game, which functions according to the erroneous definition that the majority is entitled to rule the minority).

268. Paul Magnarella, Preventing Interethnic Conflict and Promoting Human Rights Through More Effective Legal, Political and Aid Structures: Focus on Africa, 23 GA. J. INT'L \& COMP. L. 327, 330 (noting that "ethnonationalism or politicized ethnicity represents a major legitimator and delegitimator of regimes. A government's legitimacy rests, in significant degree, on its ability to convince the governed that it either shares, represents, or respects their ethnicity.").

269. JOSEPH, supra note 28 (arguing that ethnicity remains a vital social force in Nigeria because it is an emotionally satisfying mode of self and group assertion, and its salience increases rather than being overridden by division according to social class during the struggle for survival and material advantage in the modern sectors of the society and economy). 
of a modern state. The state has not been particularly successful in presenting a viable and credible alternative to ethnic identification. Many citizens perceive the nation-state as ethnically motivated and incapable of treating them fairly; therefore, they are reluctant to trade-in the privileges of ethnicity for the doubtful, even dubious, benefits of a nation-state. ${ }^{270}$ Demanding allegiance to this abstract entity called the "state" requires citizens to ignore their life experiences ${ }^{271}$ in the name of altruism, a move that is nonsensical and economically unwise. ${ }^{272}$ Loyalty to the nation will only make sense if political elites have the courage and the will to attack the social forces that militate against national unity. ${ }^{273}$

270. Anthony Anghie, Human Rights and Cultural ldentity: New Hope for Ethnic Peace, 33 HARV. INT'L L.J. 341, 347 (1992) (noting that citizens are unwilling to surrender the known and felt securities provided by their ethnic affiliations for the uncertain benefits of an emerging state).

271. The average Nigerian takes great pride in his ancestry and will only support programs or policies that do not compromise values dear to his ethnic group. Moreover, there exists a prevalent perception that the dominant Hausa ethnic group is using the machinery of state as a subterfuge to forcibly assimilate other ethnic groups. Geertz's observation in 1971 regarding ethnic groups' fear of domination remains valid in contemporary Nigeria. He stated:

To subordinate these specific and familiar identifications in favor of a generalized commitment to an overarching and somewhat alien civil order is to risk a loss of definition as an autonomous person, either through absorption into a culturally undifferentiated mass or, what is even worse, through domination by some other rival ethnic, racial, or linguistic community that is able to imbue that order with the temper of its own personality.

CLIFFORD GEERTZ, THE INTERPRETATION OF CULTURES (1973).

272. Jackson, supra note 30 , at 1 (noting that citizenship means little and carries few substantial rights or duties compared with membership in a family, clan, religious sect, or ethnic community. Ofien the government cannot govern itself, and its officials may in fact be freelancers, charging what amounts to a private fee for their services. The language of the state may be little more than a façade for the advancement of personal or factional interests by people who are only nominally judges, soldiers, bureaucrats, policemen, or members of some other official category. In short, many states in sub-Saharan Africa are far more credible realities.).

273. S.I.O. Okita, Ethnic Identity and the Problem of National Integration in Nigeria, 55 NIG. MAG. 61, 64 (1987). Okita attributes Nigeria's inability to forge a sense of nationhood to the lack of political will.

Unfortunately, the search or quest for nation building and national integration has largely been one of a grope in the dark. This grope in the dark is characterized by changing from one type of constitution to another and setting up one probe or tribunal after another .... This situation has been brought about not because as a people we lack ideas to formulate and fashion a constitution that will serve our purpose, or lack of expertise on the part of government functionaries to deal with issues being probed by panels or tribunals. What is lacking, on the part of our leadership, whether civilian or military[,] is the will to forge a strong national outlook and orientation around which a sense of identity, loyalty and belonging can be built by the citizenry. 


\section{B. Attacking Social Forces That Engender Ethnicity}

Social equilibrium cannot be imposed on society or attained through constitutional reforms alone. Nigeria must devise strategies for counteracting the constraining effects of social forces that promote ethnicity. Much of the effort at starting democracy has gone into the creation of legal rules and establishment of political institutions. These efforts go on the popular but incorrect assumption that entrusting the governance of the country to democratically elected leaders is enough to satisfy the major requirements of democracy. ${ }^{274}$ Nigeria has expended little effort to devise strategies for counteracting the social forces that paralyze democracy. Constitutional reforms, by themselves, scarcely produce stability because legal rules, however efficacious, cannot alter the psychology of citizens. ${ }^{275}$ Moreover, frequent constitutional changes in some respects inhibit social equilibrium. Such reforms often produce the unintended consequence of making citizens believe that their problems lie with the rule, thus ignoring the underlying social problems.

Legal rules are necessary but never sufficient to resolve inter-ethnic conflicts. Social equilibrium through constitutional democracy can be achieved only through cultivating a culture that respects citizens' rights, involving all ethnic groups in the process of governance, and fairly distributing the nation's resources to all ethnic groups. Education may serve as a vehicle to strengthen and promote understanding of democratic traditions. Education should focus on two main areas: changing the political philosophy and overcoming the adverse effects of illiteracy, poverty and corruption. The major goal of education should be to change the attitude of both the political leaders and the governed. Politicians must be educated to change their perception of the political process ${ }^{276}$ so they see that democracy

Id.

274. Stephen Schnably, The Santiago Comment as a Call to Democracy in the United States: Evaluating the Organization of American States Role in Haiti, Peru and Guatemala, 25 U. MIAMI INTER-AM. L. REV. 393, 524 (1994) (noting that it would be unfortunate if simply restoring elected heads of government came to be regarded as sufficient to vindicate democracy).

275. Stephen Ellmann, The New South African Constitution and Ethnic Division, 26 Colum. Hum. RTS. L. REv. 5 (1994):

The peril of ethnic division cannot be ignored. Reducing that peril by constitutional means is no simple task, for when ethnic groups pull in different directions a free country can only produce harmony between them by persuading each to honor some claims of the other and to moderate some claims of its own. It will require much more than technical ingenuity in constitution-writing to generate such mutual forbearance.

276. General Mohammed, then Head of State, in his inaugural address to the Constitution Drafting Committee, admonished that "politics must be transformed from its previous scenario of bitter personal wrangles into a healthy game of political argument and discussion." 
is not simply a power game in which the winners impose their preferences on the losers. Politicians must be educated to appreciate and respect the central tenets of democracy, a process in which a pluralistic society, comprising citizens from diverse ethnic and social backgrounds, organizes itself and resolves its differences through established channels. Political elites must rise above ethnic, sectional, and selfish interests and commit themselves to the welfare of the nation. Political leaders' chief aim, according to Lewis, should no longer be to "[c]apture the government in order to benefit one group at the expense of another but rather to represent the views of their sectional group of supporters and prepare to govern in coalition with the leaders of other parties and groups." 27 Education can also change ignorance-driven sentiments about the democratic process. Education may emphasize and reinforce the basic tenets of civil society: subordination of the military to civilian authority, respect for constituted authority, and resolution of conflicts through established procedures. Education must also promote a culture of religious tolerance, tolerance that not only refrains from injecting religion into civil affairs, but also deeply resents preference of one religion over others. We must respect our pluralism and allow citizens to profess their religion without restraint. The ultimate goals of education must be to encourage citizens to coexist peacefully and to change their negative perceptions about other ethnic groups and the political process. We must educate ethnic groups to view others not as rivals or even threats, but as fellow citizens equally committed to peace and social equilibrium.

Ultimately, education becomes a question of values and how best to translate them into reality. Politicians are members of the society, products of its cultural synthesis; they often do not and cannot rise above their communities. It is doubtful whether education can cause wholesale behavioral changes given Nigerians' demonstrable lethargic attitude toward change. Moreover, education leaves undisturbed the fundamental problem that historically has plagued the process: the unfair treatment meted out to other ethnic groups by the dominant Hausa group. This is why the next option becomes crucial.

\section{Partitioning the Nation}

Nigerian boundary lines, like those of most African nations, were arbitrarily drawn with scant regard for the well-being of the inhabitants. ${ }^{278}$

NigERIAN CONSTITUTION DRAFTING COMMITTEE, 1 REPORT OF CONSTITUTION DRAFTING COMMITTEE xii (Federal Ministry of Information 1976).

277. LEwIS, supra note 267 , at 83-84.

278. ANTHONY SMITH, THEORIES OF NATIONALISM xxxiv (1983) (noting that African boundary lines were drawn by colonial masters at the 1885 Berlin conference "in complete disregard for the cultural preferences and ethnic sympathies of their populations"). 
Even the imperialists recognized that the boundary lines were arbitrarily drawn and that national boundaries failed to take into account pre-existing relationships. An after-dinner speech by Lord Salisbury, then British Prime Minister, provided some insight into the mindset of the imperial masters who demarcated the boundary lines. At the end of the Anglo-French convention, which officially designated imperial spheres of influence in West Africa, he stated that "we have been engaged in drawing lines upon maps where no white man's foot ever trod; we have been giving away mountains and rivers and lakes to each other, only hindered by small impediment that we never knew exactly where the mountains and rivers were. ${ }^{279}$ Another British official, who was involved in creating the boundary between Nigeria and Cameroon, spoke similarly about the Nigerian boundaries:

In those days we just took a blue pencil and a rule, and we put it down at Old Calabar, and drew that line to Yola . . . . I recollect thinking when I was sitting having an audience with the Emir [of Yola] surrounded by his tribe, that it was a very good thing that he did not know that $I$, with a blue pencil, had drawn a line through his territory. ${ }^{280}$

The creation of the Nigerian nation was rooted in greed, fueled by the arrogant belief that the colonial masters knew what was best for Africans. ${ }^{281}$ Compelling hitherto homogenous and autonomous ethnic groups to exist as one nation significantly enhanced the potential for conflicts and rivalries. ${ }^{282}$ As Jennifer Parmelee aptly observed: "[B]oundaries that ignored African

279. J.C. ANENE, THE INTERNATIONAL BOUNDARIES OF NIGERIA 1885-1960, at 3 (1970).

280. Id. at 2-3.

281. Scarcely any doubt or question persists about the selfish and economic motives behind the demarcation of Africa in the nineteenth century. See, e.g., Crawford Young, The Heritage of Colonialism, in WORLD POLITICs 19 (John W. Harbeson \& Donald Rothschild eds., 1991) (noting that Africa, in the rhetorical metaphor of imperial jingoism, was a ripe melon ready for carving in the late nineteenth century. Those who scrambled fastest won the largest slices and the right to consume at their leisure the sweet succulent flesh. Stragglers snatched only small servings or tasteless portions. Italians, for example, found only desserts on their plates.); Mutua, supra note 40, at 1115 n.6 (noting that "[m]ost African states are the product of the competitive subjugation of the continent by Great Britain, France, Belgium, Portugal, Italy, and Spain between 1875-1900").

282. Mutua, supra note 40, at $1115 \mathrm{n} .8$, blames the perennial ethnic problems in Africa on colonial policy that grouped diverse ethnic groups under one nation.

Severe cleavages, those which have been a major source of the persistent problem of the African state, are the direct result of the imposition of colonial rule and the modern state. Ethnic rivalries have arisen because previously independent and self-governing ethno-political nations, characterized in almost all cases by cultural, linguistic, and ethnic homogeneity, have been coerced to live together under single states.

Id. 
realities, haphazardly slicing through tribal territories . . . have made Africa uniquely susceptible to tribalism's centrifugal pulls . . . . Most of the continent's civil wars, more than twenty in three decades, have had a significant ethnic component." 283

Nigeria, from its very inception, was doomed to fail. The country that attained independence in 1960 was "not really a nation, but rather a conglomeration of ethnic groups, with three predominating. ${ }^{n 284}$ Assembling ethnic groups with dramatically different cultural and political assumptions under the umbrella of a nation was a flawed tactic, a mistake that plagues the nation till this very date. ${ }^{285}$

In 1884-1885 the European imperial powers met in Berlin and without the consent or the participation of the African people, demarcated the continent of Africa into colonies or spheres of influence. In many cases, kingdoms or tribes were split with such reckless abandon that they came under two or three European imperial powers. This event was the genesis of many present-day conflicts and virtually insoluble problems in the African continent. ${ }^{286}$

Boundaries artificially demarcated for powerless and unsophisticated rural nineteenth-century African societies can hardly satisfy the aspirations of a

283. Jennifer Parmelee, Africa: Bloodied, Torn at its Ethnic Seams, WASH. POST, July 14, 1994, at Al.

284. M.G. Kaladharan Nayar, Self Determination Beyond the Colonial Context: Biafra in Retrospect, 10 TEX. INT'L L.J. 321, 324 (1975).

285. Deng, supra note 71 , at 34.

[T] colonial nation-state . . . brought together diverse groups that it paradoxically kept separate and unintegrated. Regional ethnic groups were broken up and affiliated with others within the artificial borders of the new state, with colonial masters imposing a superstructure of law and order to maintain relative peace and tranquility .... It can credibly be argued that the gist of these current internal conflicts is that the ethnic pieces put together by colonial glue and reinforced by the old cold war world order are now pulling apart and reasserting their autonomy.

Id. This phenomenon is not peculiar to Africa. The artificial demarcation of Europe by the Allied forces following World War II accounts for some of the unrest in the former Soviet Republic and Yugoslavia. See generally HURST HAANUM, AUTONOMY, SOVEREIGNTY, AND Self Determination (1990); Angela M. Lloyd, The Southern Sudan: A Compelling Case for Secession, 32 Colum. J. TRANSNAT'L L. 419, 423 n.17 (1994):

Recurrent violence in the former Soviet Union and Yugoslavia and the bifurcation of Czechoslovakia into separate republics . . . serve as poignant examples of the fact that the forced incorporation of diverse ethnicities into artificially delineated states neither fulfilled 'national' aspirations for autonomy nor engendered any lasting sense of 'nationalism' in the state.

286. T.O. ELIAS, AFRICA AND THE DEVELOPMENT OF INTERNATIONAL LAW viii (1988). 
twenty-first century continent. ${ }^{287}$ Economic and social development, increased political awareness, and education have increasingly focused attention on the propriety of nineteenth-century boundaries drawn by imperial fiat. 288 Also, the inequities suffered by minority ethnic groups have led repeatedly to the clamor for separate nations. The unsuccessful 1967 secessionist attempt by Ibos in Nigeria ${ }^{289}$ and the more recent demands by the Ogonis for a separate nation accurately depict widely shared partition sentiments by ethnic minorities in Nigeria. 290

Some ethnic groups have realized that independence did not translate into the end of oppression, and the beginning of justice and economic prosperity. As Albie Sachs noted:

[T] even for the formerly oppressed. History unfortunately records many examples of freedom fighters of one generation who became the oppressors of the next. Sometimes the very qualities of determination and sense of being involved in a historic endeavor which give freedom fighters the courage to raise the banner of liberty in the face of barbarous repression, transmute themselves into sources of authoritarianism and historic forced marches later on. On the other occasions, the habits of clandestinity and mistrust, of tight discipline and centralized control, without which the freedom fighting nucleus would have been wiped out, continue with dire results into the new society. ${ }^{291}$

Self-government and constitutional democracy have frequently produced the twin evils of exclusion of minority groups from the governance process and human rights violations. ${ }^{292}$ The democratic process, especially the principle

287. Helman \& Ratner, supra note 8, at 5 (noting that it is impossible to be certain that the political boundaries created under colonialism will in the end prove sustainable).

288. Magnarella, supra note 268 , at 330 , notes:

Despite the ethno-nationalist rhetoric following World War I, most of the emerged states were not true "nation-states." Most incorporated multi-ethnic populations and subsequently experienced inter-ethnic conflict. Today many states are wrestling with two conflicting principles: 1) the right of nations to self determination; and 2) the inviolability and political integrity of sovereign territory, regardless of how that territory may have been acquired or how culturally diverse its population may be.

289. For an account of the Biafran secessionist attempt, see ST. JORRE, supra note 19.

290. For a detailed study of Ogoni demands, see Osaghae, supra note 227.

291. Albie Sachs, The Future of Constitutional Position of White South AFRICANS 108-09 (1990), in Adrien Wing, Towards Democracy in a New South Africa, 16 MICH. J. INT'L L. 689, 691-92 (1995).

292. See The FaIluRe of the Centralized State, supra note 11; Collapsed States, supra note 7. 
of majoritarian supremacy, has been used to justify marginalization of minority ethnic groups. For example, both the parliamentary system of government practiced between 1960 and 1966 and the presidential system introduced in 1979 go on the assumption that majority rule is the essence of democracy. Because political alignments run along ethnic lines, democracy often produces permanent minorities. This is especially true in Nigeria, where some ethnic groups are much bigger than others. ${ }^{293}$ The Hausa ethnic group, the biggest in Nigeria, has produced more presidents than have all the other ethnic groups combined. ${ }^{294}$ The Hausa's record of marginalizing other ethnic groups has tremendously affected the search for social equilibrium in Nigeria: citizens from other ethnic groups are less inclined to play by the rules and sometimes behave in ways inimical to the overall interest of the nation. ${ }^{295}$ In pluralistic societies, democracy can only translate into social equilibrium if the majority voluntarily checks its excesses and avoids actions that threaten the minority's existence.

Voluntary self-restraint is an exorbitant commodity in Nigeria, given a pervasive culture and a long history of arrogance. In Nigeria, as in most developing nations, cases abound where the majority ethnic group forcibly tries to impose its cultural and religious preferences onto other ethnic groups. ${ }^{296}$ Minority ethnic groups' opposition to this forced conformity and injustice results in conflicts. ${ }^{29}$ A movement toward heightened ethnic consciousness results in a call for an end to injustice and, more fundamentally, a call for partition. Only a nation of their own can satisfy minority groups' quest for freedom and guarantee both control of their destinies and a brighter future for their children. ${ }^{298}$

293. See Coleman, supra note 26.

294. The only exceptions are General Ironsi, an Ibo, who ruled from January to July, 1966, and General Obasanjo, a Yoruba, who ruled from 1976 to 1979. General Obasanjo assumed office following the assassination of General Mohammed.

295. RABUSHKA \& SHEPSLE, supra note 216, at 90 (noting that "majoritarianism" is the cause of the dominant community and their paradigm of politics in plural societies involves the sectional domination of decisional processes, a decline in democratic competition, electoral machination and political violence resulting in the destabilizing of the whole polity).

296. Forced assimilation techniques range from the damnable ethnic cleansing to exclusion from power.

297. Magnarella, supra note 268 , at 333 (noting that “[a]ttempts by state governments to force diverse cultural populations into the majority ethnic mold have frequently led to human rights abuses").

298. Despite stiff opposition from international bodies and super powers, partitioning is gaining currency in the world. Eriterea broke away from Ethiopia and became an independent state in 1993. The former Soviet Union was broken into fifteen independent states: Armenia, Azerbaijan, Belarus, Estonia, Georgia, Kazakhstan, Kyrgyzstan, Latvia, Lithuania, Moldova, Russia, Tajikstan, Turkmenistan, Ukraine, and Uzbekistan. The former Yugoslavia was partitioned into six separate sovereign states: Bosnia-Herzegovina, Croatia, Macedonia, Slovenia, Serbia, and Montennegro. See Russell W. Howe, Countries Are Breaking into 
Persistent clamor for statehood raises crucial questions: should African nations continue to ignore the enormous costs, human and material, involved in forcing unwilling ethnic groups to coexist? How long will African nations endure the pains of statehood inflicted on them by colonial masters for purely selfish reasons? Do Europeans, who arbitrarily thrust nationhood on unwilling and ill-prepared ethnic groups, have a moral responsibility to help African nations in finding a solution to the problem? ${ }^{299}$

African countries, upon attaining independence, had two basic options: redraw boundary lines to correct the errors of colonialism or accept the borders drawn by the imperialists. Opinions have differed considerably depending upon sentiments of the agitators. Some condemned the boundary lines arbitrarily drawn by colonial masters and called for "the abolition or adjustment of such frontiers at an early date." ${ }^{300}$ Others, especially political elites eager to assume the reigns of power, felt that restructuring borders would delay the attainment of independence and "opted for maintaining extant lines as the most feasible method for speedy decolonization." 301

Neither time nor circumstance has dulled the relevance of revisiting African border lines. Once overshadowed by the struggle for independence and endemic ethnic conflicts, political and economic crises in Africa continue to bring to the fore the highly controversial question of redrawing boundary lines. ${ }^{302}$ Some writers recognize that ethnic conflicts are endemic in Africa

Ministates and That's not Necessarily Bad, BALTIMORE SUN, Jan. 1994, at E8.

299. There is debate, largely academic, about what the appropriate response should be. Some advocate recolonization as the solution to Africa's political problem. See, e.g., William Pfaff, A New Colonialism? Europe Must Go Back to Africa, 74 ForeIGN AFF. 1 (1995). Ali Mazrui, one of Africa's leading scholars, argues that the successive collapse of the state in one African country after another creates the need for recolonization of Africa. See Ali Mazrui, The Message of Rwanda: Recolonize Africa? N. PERSP. Q., Fall 1994, at 18 . The recolonization proposed by Mazrui rests on humanitarian grounds and differs from European colonization because Africans would supervise it. Under the proposal, an African Security Council composed of five African states-Egypt, Ethiopia, Zaire, South Africa, and Nigeriaacting in concert with the United Nations, will restore peace and order in troubled African states. See Ali Mazrui, Maybe Time Has Come to Recolonize Africa, Houst. Chron., Aug. 3,1994 , at A27. Other suggestions include setting up a trusteeship under the auspices of the United Nations whereby the U.N. would act as the administering authority in troubled states. See Helman \& Ratner, supra note 8, at 3.

300. See Colin Legum, Pan Africanism: A Short Political Guide 228, 231 (Resolutions Adopted by the All-African People's Conference, Accra, Dec. 5-13). One of the resolutions condemned artificial frontiers drawn by imperialist powers to divide the peoples of Africa and called for the abolition or adjustment of such frontiers at an early date.

301. Steven Ratner, Drawing A Better Line: Uti Possidetis and the Borders of New States, 90 AM. J. INT'L L. 590, 595 (1996). Ian Brownlie also notes that “Africa[n] boundaries which intersected ethnic territories were retained after independence to avoid disputes and threats to peace in Africa." IAN BROWNLIE, BASIC DOCUMENTS ON AFRICAN AFFAIRS 360 (1971).

302. Richard Mukisa identifies three factors as being responsible for rekindling the 
but contend that partitioning would not be the best cure. Opponents of partition argue that granting desirous ethnic groups the right to secede will result in the proliferation of nations. One writer rules out partition as an option and maintains that "Africa is too integrated to be retribalized and too poor to be chopped up further into beggar republics." 303 Some also argue that complaining minorities and a domineering majority will always exist. Redrawing boundary lines might, therefore, serve only to reproduce problems that lead to agitation for separate states. ${ }^{304}$ A 1922 report submitted to the United Nations by the Commission of Rapporteurs on the Aaland Island Question stated:

To concede to minorities, either of language or religion, or to any fractions of a population the right of withdrawing from the community to which they belong, because it is their wish or their good pleasure, would be to destroy order and stability within states and to inaugurate anarchy in the international life. ${ }^{305}$

Even in the face of overwhelming evidence of civil strife, partition demands Nigeria face two seemingly insurmountable obstacles. First, international organizations, including the United Nations and the Organization of African Unity, are reluctant to assist ethnic groups seeking autonomy as such bodies have consistently favored the inviolability of a nation's sovereignty and territorial integrity. The Organization of African Unity (OAU) has ill-advisedly emphasized the inviolability of existing boundary lines and refused to review partition demands by oppressed minorities. ${ }^{306}$ The OAU, as far back as 1963, resolved "to respect the

discussion about redrawing Africa's boundary lines: (1) the determination of the African political leadership to resolve the continent's current economic crisis; (2) Africa's increasing realization that peace and security are the prerequisites for the economic development of the continent; and (3) the urgent need to curb political crisis. Richard S. Mukisa, Toward a Peaceful Resolution of Africa's Colonial Boundaries, 44 AFR. TODAY 7 (1997).

303. Pauline Baker, Carving up Africa Isn't the Way to Help, INT'L HERALD TruB., Aug. 9, 1994.

304. Former United States Secretary of State Warren Christopher stated at his confirmation hearing that "[i]f we don't find some way that the different ethnic groups can live together in a country, how many countries will we have? . . . We will have 5000 countries rather than the hundred plus we now have." David Binder, As Ethnic Wars Multiply, United States Strives for a Policy, N.Y. TIMES, Feb. 7, 1993, at 1.

305. Report Presented by the Comm. of Rapporteur on the Aaland Islands Question, League of Nations Doc. C. 21/68/106 VII, at 28 (1921).

306. See ORGANIZATION OF AFRICAN UNITY CHARTER, 479 U.N.T.S. 39, 2 I.L.M. 766 (1963). Article II of the Organization of Africa Unity Charter enjoins member states to defend their territorial integrity and independence. Article III further requires member states to "solemnly affirm and declare their adherence to the principle of respect for the sovereignty and territorial integrity of each state and for its inalienable right to independent existence." 
frontiers existing on their achievement of independence. ${ }^{307}$ The OAU stand, in effect, puts the ethnic groups on notice that partition or redrawing border lines would never be an option. The United Nations, for its part, hides under the policy of non-interference in internal affairs of states to deny assistance to ethnic groups fighting for partition. ${ }^{308}$ Ethnic groups desirous of asserting a right of self-determination find themselves in a quandary: alienated from the political process, often robbed of their rights and brutally denied the right of self determination. Henry Richardson succinctly captures the plight of minority ethnic groups and the attitude of African governments:

A state may indeed be disintegrating because its government will not justly represent the fundamental interests of a dissident defined people who may be occupying a designated territory. Secession being illegal and cession being a loss of political face to the ceding national government, military force is all too often called upon, justified not only under claims of law prohibiting secession but under various slippery slope arguments advocating suppression as the only remedy against the dissolution of the entire national state. ${ }^{309}$

National sovereignty and territorial integrity should be respected so long as ethnic groups' rights to self-determination and basic human rights are not compromised. International agencies should anchor the much taunted search for new world order on self-determination and respect for human rights, rather than on national sovereignty. ${ }^{310}$ In contrast, a policy that emphasizes national sovereignty over self-determination will simply embolden despotic regimes and majority groups to engage in acts of oppression and human rights violations. Nations should be encouraged to redraw boundary lines whenever the current government fails to meet the

307. BROWNLIE, supra note 301, at 361 (quoting OAU Resolution on Border Disputes (1964)).

308. The United Nations has limited its involvement to peace-keeping, placing itself between two opposing factions (Somalia and Bosnia are two recent examples). See H.E. Boutros Boutros-Gali, Beyond Peace Keeping, 25 N.Y.U. J. INT'L L. \& POL. 113, 114-15 (1992). United Nations peace-keeping efforts proceed under two broad heads. First, where the warring parties exhibit the political will necessary for a successful intervention (i.e. willing to keep the peace), the United Nations will intervene and keep the peace. Examples include Cambodia, Mozambique, Namibia and El Salvador. The second is where the United Nations intervenes regardless of the consent of the parties. Examples include Somalia and Rwanda. Id. at 116-17.

309. Henry Richardson III, "Failed States," Self-Determination, and Preventive Diplomacy: Colonialist Nostalgia and Democratic Expectations, 10 TEMP. INT'L \& COMP. L.J. 1, 45 (1996).

310. For an interesting analysis of the central tenets of the new world order, see Ernest Easterly III, The Rule of Law and The New World Order, 22 S.U. L. REV. 161 (1995). 
aspiration of its people. To continue to ignore minority rights violates basic standards of decency and makes a mockery of human rights championed by the United Nations and the "super powers."

The second impediment to redrawing boundary lines is national governments' adamant opposition to such a measure. The Nigerian government, ostensibly encouraged by international bodies' commitment to national sovereignty, remains adamantly committed to the nineteenth-century boundary lines. Even in the face of imminent disintegration, the Nigerian military regime has squelched all attempts to discuss the option of partition. ${ }^{311}$ Nigeria's blind and unquestioning commitment to national boundaries contradicts sentiments expressed at the West African Conference held in Berlin, at which Africa was demarcated. The conference implicitly conceded that national boundaries are not cast in stone: "Possibilities and new requirements will probably reveal themselves and the time may arrive when a wise foresight will demand the revision of a system which was primarily adapted to a period of creation and of change." 312 Nigeria, like all nations plagued by ethnic conflicts, must weigh and balance the benefits of partition against the dubious benefits of national sovereignty. African countries should critically and dispassionately re-examine boundary lines to assess the effect of existing boundary lines on social equilibrium. African nations need to determine whether they can afford adamant commitment to national sovereignty, especially in the face of overwhelming evidence of ethnic strife and social unrest. Social equilibrium enjoyed by countries that have been successfully partitioned clearly demonstrate that the benefits of partition far outweigh the need for preserving a nation's territorial integrity. ${ }^{313}$

Dramatic changes in Nigeria and the African continent demand that we revisit the boundary lines artificially drawn in the nineteenth century..$^{314}$ Boundary lines are not cast in stone; they can and should be changed if doing so will promote peace and equilibrium. Nigerian and indeed all African nations should listen to Richard Mukisa, who advised: "One must avoid the

311. General Sanni Abacha, Nigeria's current head of state, recently stated that "the country's unity is not a subject for negotiation." Abacha Says Country's Unity Non-Negotiable at Constitutional Conference (BBC Summary of World Broadcast, Dec. 13, 1993).

312. General Act of the Berlin West African Conference, art. 36 and annex 3 to protocol no. 9 of the General Act, reprinted in R.J. GAVIN \& J.A. BETLEY, THE SCRAMBLE FOR AFRICA:DOCUMENTS ON THE BERLIN WEST AFRICAN CONFERENCE AND RELATED SUBJECTS $1884 / 1885$, at $278-300$ (1973).

313. Relative peace in the former Soviet Union and the former Yugoslavia amply illustrate that Balkanization can lead to peace.

314. Herbst, supra note 223, at 203 (commenting that so much has changed in Africa and the rest of the world, and the development record of Nigeria and other countries has been so stark that the principle that Africa cannot change the nature of its governing units should be thrown open to debate). 
temptation to view the present patchwork of countries on the map of Africa as unchangeable and indispensable. Instead, the focus should be on how to peacefully reorganize the patchwork to maximize the prospects for Africa to become a zone of peace and prosperity. ${ }^{\text {315 }}$

Nigeria as presently constituted has no answer to the coming anarchy, chiefly because various ethnic groups are pitted irredeemably against each other. Restoration of a civilian administration simply masks the problem or perhaps changes its dynamics or size. The calm that currently exists in Nigeria is due to the attitude of the current military dictatorship that sternly sets its face against all kinds of agitations and complaints. ${ }^{316}$ Numbing ethnic tensions have been a simple task for brutal military dictators who easily choke off ethnic agitations by intimidation. Restoration of a civilian administration will provide a climate and opportunity for ethnic groups to express their concerns. Freed from the pangs of despotism and emboldened by the freedoms conferred by the democratic process, ethnic groups will renew their age long rivalries and agitation for increased access to the machinery of government. ${ }^{317}$ Civilian administration will "lay bare ethnic tensions that have long simmered under the suppression of a dictator's boot." 318

The only way to prevent the coming anarchy is to redraw boundary lines. Boundary lines can be peacefully redrawn; bloodshed is neither necessary nor inevitable. Existing boundary lines need not be "washed clean with buckets of blood." ${ }^{\text {119 }}$ Redrawing boundary lines is an effective way of numbing ethnic tensions and conflicts that threaten social equilibrium in Nigeria. Nigeria can be broken into three countries, along the lines of the three predominant ethnic groups. The first nation should comprise of states in the old Northern province. The second nation should consist of states in the old Western Nigeria. The third nation should comprise of states in the old Eastern Nigeria. These suggested nations are merely illustrative and not definitive. I proffer the creation of these states to provoke serious discussion

315. Mukisa, supra note 302, at 21.

316. Adams, supra note 20 , at 29 (noting that the army may be the only institution able to run this unwieldy country as one and its short-term horizons (controlling and benefitting from oil money) are taking their toll on a corrupt, wasteful, and spectacularly mismanaged economy); Benjamin Schwarz, The Diversity Myth: America's Leading Export, ATLANTIC MONTHLY, May 1, 1995, at 57 (noting that stability within divided societies is normally based on some form of domination and once internal differences become violent, usually only the logic of force can lay them to rest).

317. Schwarz, supra note 316, at 57 (commenting that democracy, which permits-in fact encourages-competition for power and benefits among contesting groups, actually exacerbates internal tensions and conflicts).

318. Darton, supra note 89.

319. Ali Mazrui, The African State as a Political Refugee: Institutional Collapse and Human Displacement, INT'L J. REFUGEE, July 1995, at 22. 
and good faith inquiry into the problems of post-independent Nigeria. Whatever boundary lines that ultimately emerge should be predicated on consent and voluntary association of all the parties involved. Unlike the imperialists who based boundary lines on geographical features, ${ }^{320}$ the central focus of the Balkanization process should be to preserve the cultural homogeneity of the disparate ethnic groups that now comprise the nation called Nigeria. Partition along ethnic lines worked for Europe; nothing suggests that redrawing boundary lines will not produce similar results in Africa. ${ }^{321}$

Partitioning ethnic groups with common language, religion, and cultural and political ethos into one nation will make it much easier for civil society to develop into a nation-state, thus preventing many tensions posed by the existence of three parallel societies within one nation. ${ }^{322}$ New nationstates consisting of homogenous groups will be in a much better position to devise political and legal structures that will preserve the heritage and custom of its inhabitants.

The fear that partition will increase demands for self-determination is not persuasive in Nigeria. Partition demand in Nigeria rests entirely upon a different assumption: to correct the errors of colonialism. ${ }^{323}$ The three

320. IAN BROWNLIE, AFrICAN BOUNDARIES: A LEgAL AND DIPLOMATIC ENCYCLOPEDIA $6(1979)$.

321. WASH. TIMES, Apr. 26, 1994, at A18. Sam Onwuesbu notes that "Europe has been divided into bits and pieces along ethnic lines-England, France, Ireland, the Netherlands, Italy, Germany, Sweden, Denmark, Poland, Greece, etc. If these ethnic partitions were good for Europe, they would be perfect for Africa." Id.

322. See Art Hansen, African Refugees: Defining and Defending Their Human Rights, in HuMAN RIGHTS AND GovernaNCE IN AFRICA 161-62 (Ronald Cohen et al. eds., 1993):

The term 'nation' refers to a group that shares a common history and identity and is aware of that; they are a people, not just a population. Using that definition, ethnic groups (once called tribes) in Africa are also nations. None of the new African states were originally nation-states because none of them were nations as well as states. Each of the new states contains more than one nation. In their border areas, many new states contain parts of nations because the European-inspired borders cut across existing national territories.

See also Abdullahi Ahmed An-Na'im, The National Question, Secession and Constitutionalist: The Mediation of Competing Claims to Self Determination, in STATE AND Constrtuttionalist: AN African Debate on Democracy 101 (Issa G. Shirji ed., 1991):

If we define a 'nation' simply as a people of common ethnicity and culture, the term nation-state is somewhat a misnomer because it is very rare for the population of a nation-state to consist of a single nation. In the vast majority of cases, and universally throughout Africa, the population of the nation-state consists of several "nations."

323. Osaghae, supra note 227 , at 343 (contending that the Nigeria federation as it presently exists is an anomaly because the various ethnic groups have not been allowed to decide whether they want to continue to belong to it or not since the British "forced" them into union in 1914). 
major ethnic groups in Nigeria are not just geographical areas; they are culturally, ethnically, and linguistically different from each other. Artificially joined by colonial fiat, they have never truly harmoniously coexisted. Peace cannot be secured by compelling culturally and linguistically different people to live together. The three major ethnic groups in Nigeria have no common bonds of nationhood; they are united by mutual disdain for one another.

A complex of factors renders a nation viable including willingness and desire to identify with and make the necessary connection with the nation. Such intangibles cannot be imposed upon the inhabitants of Nigeria. For some Nigerians, the state called Nigeria symbolizes oppression, a damnable legacy of colonialism that ensured Hausa domination. ${ }^{324}$ Fear of domination has produced a cautious, even skeptical citizenry that questions every integrationist attempt. The net result of this existence is that ethnic consciousness has been raised to such a level that most Nigerians celebrate ethnicity above the nation. No political arrangement will ever succeed in shifting allegiances from the ethnic groups to an abstract entity called Nigeria. ${ }^{325}$ It is time for the ethnic groups to part ways. Holding together and trying to democratize warring and implacable ethnic groups is a futile exercise that guarantees endless violence and postpones other political development. ${ }^{326}$

Problems in multi-ethnic countries have never been meaningfully resolved through legal rules, including constitutional democracy. Concession, compromise, observance of rules that safeguard against abuse, and love for the nation are elements that produce peace in a nation and cannot be secured through constitutional rules. Legal rules alone have never been able to negate the avalanche of ethnic distrust or transform ethnic irredentists into true nationalists. Nigeria needs to act decisively to avoid replicating the mistakes of the past. We cannot hold on to the territorial integrity at all costs. The government's failure to treat minority ethnic groups fairly has greatly compromised Nigeria's viability as a nation. How long must minority ethnic groups worship a god that is indifferent to their cause? Can we in all honesty expect citizens to be loyal to a "bankrupt and

324. The statement by a 32-year farmer interviewed by Alec Russell of London's Daily Telegraph represents widely shared negative sentiments about the Nigerian nation. The man, who had been arrested and tortured three times, stated: "Nigeria means nothing to me. . . How can you live in a place where your freedoms are denied? What we see every day is intimidation, threats and detention." DAILY TELEGRAPH (London), Oct. 1995, available in 1995 WL 8039288.

325. Magnarella, supra note 268, at 333 (noting that historically, diverse ethnic populations with a tradition of mutual animosity have not found common citizenship in a single state a sufficient basis for social harmony; on the contrary, the state form has simply become the new arena for inter-ethnic political and economic battles).

326. Schroeder, supra note 25, at 161. 
abusive entity"? ?27 In 1968, Tanzania recognized Biafra as an independent state contending that since Nigeria had failed the Ibos, they owed it no loyalty. In according recognition to Biafra, Tanzania's government noted:

When the state ceases to stand for the honor, the protection, and well being of all its citizens, then it is no longer the instrument of those it has rejected. In such a case, the people have the right to create another instrument for their protection-in other words, to create another state. ${ }^{328}$

Preserving a nation's territorial integrity is a highly desirable goal, but the blood of innocent citizens should not water it. Pursuing the vision of one Nigeria is inherently problematic and carries a tremendous potential for another civil war. In the short term, it guarantees endless military coups. Ambitious military officers will always use ethnic rivalries as a convenient excuse to intervene in the political process forcibly. When a state loses its raison d'etre, which is the provision of a safe and conducive environment for citizens to pursue material and moral upliftment, it must be dismantled..$^{329}$ Nigeria is on the brink of collapse. ${ }^{330}$ A confused military dictatorship and ethnic strife have overwhelmed all the elements that preserve equilibrium in society. ${ }^{331}$ The only way out is to partition the country. Dividing the

327. Mutua, supra note 40 , at 1165.

328. The Tanzania Government's Statement on the Recognition of Biafra, Apr. 13, 1968, in Foreign Policy of TANZANIA 1961-1968: A READER 275, 278 (Mathews \& Mushi eds., 1981).

329. See Makau Mutua, Putting Humpty Dumpty Back Together Again: The Dilemma of a Post-Colonial African State, 21 BROOK. J. INT'L L. 505, 509 (1995):

A state is not an end in itself but a means to the creation of conditions for the happiness of the highest possible number of people. When the basic premise is violated, and is no longer the rationale for the existence of the state, then it becomes questionable why anyone would advocate the "redemption" of such an entity.

See also Mazrui, supra note 319, at 23 (listing six crucial functions of statehood: exercise sovereignty and control over territory, have sovereign oversight and supervision of the nation's resources, exercise an effective and rational collection of revenue, maintain adequate national infrastructure such as roads and telephone system, have capacity to govern, and maintain law and order).

330. Diamond, supra note 12; Paul Adams, Africa's Next Pariah, AFR. REP., May-June 1995, at 45 (contending that Nigeria's gradual disintegration through collapsing infrastructure and the decline of government institutions is a real but long-term threat to the centralized state; Nigeria has been left far behind by South Africa, politically as well as economically, but the danger is that it could follow the path of Zaire: disjointed, almost ungovernable, and abandoned by the rest of the world except for a few companies interested in extracting its mineral wealth).

331. The U.S. State Department's Bureau of Intelligence and Research notes:

Nigeria is becoming increasingly ungovernable .... Ethnic and regional splits are deepening, a situation made worse by an increase in the number of states 
country into homogenous nation-states is a much better option than trying to patch the country together "with ingenious but unworkable power sharing schemes. "332

Speaking of an ingenious power-sharing scheme, the new Nigerian constitution, which takes effect in 1998, prescribes power-sharing schemes under which the presidency and key elective posts will rotate among the ethnic groups in the country. ${ }^{333}$ The Head of State, General Sanni Abacha, in his 1995 independence speech explained the reasons for a rotational presidency:

The Provisional Ruling Council decided that on the higher and long term national interest, the proposal of rotational power sharing should be accepted. This option will apply to all levels of government. The Provisional Ruling Council has also endorsed a modified presidential system in which six key executive and legislative offices will be zoned and rotated between identifiable geographical groupings. In the implementation of this provision, the country has been divided into six zones: North-east, North-west, Middle Belt, South-west, East Central and Southern minorities. The national political offices which will be filled by candidates on rotational basis are: the president, the vice president, prime minister, deputy prime minister, senate president and speaker of the house. The power sharing arrangement which will be entrenched in the constitution shall be at the federal level and applicable for an experimental period of thirty years. ${ }^{334}$

The proposal to rotate the presidency and other key elective posts among the ethnic groups implicitly acknowledges that democracy cannot work in Nigeria as presently constituted. Though the plan reflects bold moves to allay the fear of domination widely nursed by ethnic groups in Nigeria, it risks doing more harm than good. How do we decide which ethnic group will produce the first president? What happens, if after the first term, the

from 19 to 30 and a doubling in the number of local goveming authorities; religious cleavages are more serious . . . . The will to keep Nigeria together is now very weak.

Kaplan, The Coming Anarchy, ATLANTIC MONTHLY, Feb. 1994.

332. Lind, supra note 27, at 98.

333. The power-sharing scheme parallels the federalist and conscotional principles contained in the New South Africa Constitution. See ZiYad Motala, Constitutional OPTIONS FOR A NEW SOUTH AFRICA: A COMPARATIVE PERSPECTIVE (1994).

334. W. AFR., Oct. 9, 1995, at 1556 (General Sanni Abacha, 1995 Independence Anniversary Broadcast). 
military aborts the process? ${ }^{335}$ Would the division of the country into six zones not enthrone zonal loyalties at the expense of national loyalty?

Nigerians have sufficient historic justification to be skeptical about the efficacy of the power-sharing scheme. ${ }^{336}$ The history of Nigeria suggests that legal rules have no enduring significance: politicians disregard them with impunity ${ }^{337}$ and they have never bound the military. ${ }^{338}$ Nigeria has reached a point where the social realities, especially ethnic rivalries, can no longer be ignored or treated as aberrant conduct of a few that executive fiat can easily correct. ${ }^{339}$ No legal rule or power sharing, however ingenuous, can calm minority ethnic groups' apprehension of the nation-state, particularly the majority group's commitment to the minority's well-being. Nigerians must rise above this seductive, even fanciful, but untenable idea that power sharing will promote national loyalty and social equilibrium. The powersharing scheme proposed by the fourth republic starting in 1998 should be

335. Adams, supra note 20 (commenting that the debate about president by rotation is academic unless the armed forces intend to leave government to civilian hands long enough for all six regions to have their share of top political offices).

336. Professor Julius Ihonvbere's cynicism about the workability of the new rotation of power arrangement probably reflects the view widely shared by most Nigerians. He stated: This is not the first time that the idea of "zoning" or "rotating" key posts has been tried in Nigeria. It has never worked. Those who begin the process will not only want to hold onto power, but also to incapacitate others and reproduce themselves. The creation of multiple levels of authority will merely weaken government and administration in a political system where the state is the fastest avenue to capital accumulation. Moreover, without enabling civil society to accommodate popular interests, it is doubtful if the mere multiplication of political positions and rotation of power will lead to genuine democratization.

Julius O. Ihonvbere, Are Things Falling Apart? The Military and the Crisis of Democratization in Nigeria, 34 J. MOD. AFR. STUD. 193, 221 (1996).

337. Constitutional rules have no enduring significance in Africa. Constitutions, according to Green,

do not in any meaningful sense represent the goals or operating principles of any significant interest groups/sub-classes, are not seen as relevant to constitutional orders, and exist because it is believed that, like national anthems, coats of arms and flags, constitutions, and "development plans" are something that states have to have for ceremonial and formal symbolic purposes.

Reginald H. Green, Participatory Pluralism and Pervasive Poverty: Some Reflections, THIRD WORLD LEGAL STUD. 21, 27 (1989).

338. The frequency of military assumption of political authority creates considerable doubts in the minds of many Nigerians about the durability of the scheme. Upon assumption of office, the military abolishes all political institutions and structures thus rendering irrelevant all power-sharing schemes.

339. DIAMOND, supra note 12 (commenting that the country's ethnic, regional, and religious cleavages cannot be resolved by force or fiat or denial of reality; they can only be eased and managed through an open political process that takes frank stock of the fears, grievances, and resentments on all sides and then crafts a new political framework, with popular legitimacy, to enable contending groups to compete and coexist with mutual security). 
exposed for what it is: a convenient scheme designed by the ruling political elites to achieve short-term equilibrium to enable them to continue their shameless expropriation of the nation's resources. ${ }^{340}$

\section{CONCLUSION}

This paper has clearly shown that the idea of restoring social equilibrium through democracy is profoundly misconceived. Restoration of civilian administration cannot guarantee respect for human rights and preservation of democratic ideas. Brief experiments with democracy in Nigeria did not halt the phenomenon of ethnic rivalries. Oppression of minorities remained despite constitutional injunctions of equality and justice. So also did human rights violations, corruption, and exclusion of minorities from the governance process feature prominently in the political landscape. Dr. Mutua's pessimism about the workability of democracy in Africa is more well-founded than the reassurances of self-serving African political elites and their foreign cronies:

It will not suffice to democratize the post-colonial state; as a fundamentally undemocratic entity in concept and reality, it is incapable of genuine democratization. Africa's political map must first be unscrambled and the post-colonial state disassembled before the continent can move forward. Put differently, the form and physical substance of the colonial state must be completely dismantled; otherwise, its tightening noose will strangle the entire continent. ${ }^{341}$

Nigeria cannot continue the costly experiment with democracy without risking the lives of its citizens. No Nigerian citizen confronts, without a feeling of despair, the civil strife, political instability, massive human rights violations, and economic deprivations that flow from failed attempts at establishing democracy. To avoid further destruction and relieve Nigerians from the tyranny of the dominant ethnic group, partition has become an unavoidable solution. ${ }^{342}$ Wole Soyinka's message deserves more credit than

340. Democracy and transition from military to civilian administration programs hold an addictive appeal to ethnic chieftains with access to power and the national treasury. JOSEPH, supra note 28 , at 53 (characterizing democracy as a crucial defense by small groups to protect their access to the public till).

341. Mutua, supra note 40 , at 1162.

342. Professor Ali Mazrui predicts that

[o]ver the next century the outlines of most present-day African states will change in one of two main ways. One will be ethnic self-determination, which will create smaller states, comparable to the separation of Eriteria from Ethiopia. The other will be regional integration, towards larger political 
it has received:

We should sit down with square rule and compass and redesign the boundaries of African nations. If we thought we could get away without this redefinition of boundaries back when the Organization of African Unity was formed, surely the instance of Rwanda lets us know in a very brutal way that we cannot evade this historical challenge any longer. ${ }^{343}$ 
